\title{
Global Diversity of Marine Isopods (Except Asellota and Crustacean Symbionts)
}

\author{
Gary C. B. Poore ${ }^{1 *}$, Niel L. Bruce ${ }^{2,3}$ \\ 1 Museum Victoria, Melbourne, Victoria, Australia, 2 Museum of Tropical Queensland and School of Marine and Tropical Biology, James Cook University, Townsville, \\ Queensland, Australia, 3 Department of Zoology, University of Johannesburg, Auckland Park, South Africa
}

Abstract: The crustacean order Isopoda (excluding Asellota, crustacean symbionts and freshwater taxa) comprise 3154 described marine species in 379 genera in 37 families according to the WoRMS catalogue. The history of taxonomic discovery over the last two centuries is reviewed. Although a well defined order with the Peracarida, their relationship to other orders is not yet resolved but systematics of the major subordinal taxa is relatively well understood. Isopods range in size from less than $1 \mathrm{~mm}$ to Bathynomus giganteus at $365 \mathrm{~mm}$ long. They inhabit all marine habitats down to $7280 \mathrm{~m}$ depth but with few doubtful exceptions species have restricted biogeographic and bathymetric ranges. Four feeding categories are recognised as much on the basis of anecdotal evidence as hard data: detritus feeders and browsers, carnivores, parasites, and filter feeders. Notable among these are the Cymothooidea that range from predators and scavengers to external blood-sucking micropredators and parasites. Isopods brood 10-1600 eggs depending on individual species. Strong sexual dimorphism is characteristic of several families, notably in Gnathiidae where sessile males live with a harem of females while juvenile praniza stages are ectoparasites of fish. Protandry is known in Cymothoidae and protogyny in Anthuroidea. Some Paranthuridae are neotenous. About half of all coastal, shelf and upper bathyal species have been recorded in the MEOW temperate realms, $40 \%$ in tropical regions and the remainder in polar seas. The greatest concentration of temperate species is in Australasia; more have been recorded from temperate North Pacific than the North Atlantic. Of tropical regions, the Central Indo-Pacific is home to more species any other region. Isopods are decidedly asymmetrical latitudinally with 1.35 times as many species in temperate Southern Hemisphere than the temperate North Atlantic and northern Pacific, and almost four times as many Antarctic as Arctic species. More species are known from the bathyal and abyssal Antarctic than Arctic GOODS provinces, and more from the larger Pacific than Atlantic oceans. Two areas with many species known are the New Zealand-Kermadec and the Northern North Pacific provinces. Deep hard substrates such as found on seamounts and the slopes are underrepresented in samples. This, the documented numbers of undescribed species in recent collections and probable cryptic species suggest a large as yet undocumented fauna, potentially an order of magnitude greater than presently known.

\section{Introduction}

Isopod crustaceans occupy all habitats, from the desert to the deep sea with the exception of terrestrial Antarctica. Marine species (those that breed in marine or estuarine habitats) are known from the supralittoral and intertidal to depths in excess of six kilometres. Isopods are a highly diverse group of crustaceans, with more than 10,300 species known to date, approximately 6,250 of these being marine or estuarine. In the groups under discussion here (about half the species) the vast majority of species are known from depths of less than 1000 metres.

The Isopoda is one of the orders of peracarid crustaceans, that is, those that brood their young in a marsupium under the body. They are uniquely defined within Peracarida by the combination of one pair of uropods attached to the pleotelson and pereopods of only one branch. Marine isopods are arguably the most morphologically diverse order of all the Crustacea. Many species have a dorsoventrally compressed body shape, usually with a vaulted dorsum, notably the Cymothoida and the family Sphaeromatidae. The Anthuroidea exhibit bodies that are extremely elongate and cylindrical (vermiform) while the Serolidae and some Sphaeromatidae are strongly flattened (scale-like). The Valvifera and Sphaeromatidae may display a high degree of ornamentation in the form of spines and nodules. Most are bilaterally symmetrical but some parasitic cymothoids are variously twisted. Sexual dimorphism in body shape and mouthparts is common in many families.

\section{Methods}

This contribution reviews the diversity of the marine Isopoda exclusive of the Asellota (planned by G.D.F. Wilson for this journal) and those isopods that are symbionts of marine crustaceans, namely the Bopyroidea and Cryptoniscoidea [1]. The taxa with numbers of species are listed in Table 1 and representative taxa are shown in Figure 1. Therefore all text relates to cymothooidean superfamilies Cymothooidea and Anthuroidea, and suborders Limnoriidea, Valvifera and Sphaeromatidea. Historic references are not cited but can be readily accessed through references cited here and World List of Marine, Freshwater and Terrestrial Isopod Crustaceans available in two formats, one hosted at the Smithsonian Institution [2] and the other as part of WoRMS (World Register of Marine Species,

Citation: Poore GCB, Bruce NL (2012) Global Diversity of Marine Isopods (Except Asellota and Crustacean Symbionts). PLoS ONE 7(8): e43529. doi:10.1371/ journal.pone.0043529

Editor: Brian R. MacKenzie, Technical University of Denmark, Denmark

Published August 31, 2012

Copyright: (c) 2012 Poore, Bruce. This is an open-access article distributed under the terms of the Creative Commons Attribution License, which permits unrestricted use, distribution, and reproduction in any medium, provided the original author and source are credited.

Funding: The authors have no funding or support to report.

Competing Interests: The authors have declared that no competing interests exist.

*E-mail: gpoore@museum.vic.gov.au 
hosted at the Belgian Institute of Marine Science (VLIZ)) [3]. Data sources are current at the end of 2010. The Sphaeromatid Isopods Worldwide resource [4] was also consulted. The primary data source is the WoRMS database, augmented for general biology and ecology by our own experience with the fauna and literature. To appreciate how marine isopods are distributed globally, species records have been allocated to one or other of two biogeographic schemes according to bathymetric records: (1) realms of the Marine Ecoregions of the World (MEOW) which is a bioregionalization of coastal and shelf areas [5] (Table 2, Fig. 2A); or (2) lower bathyal provinces (800-3000 m) of the Global Open Oceans and Deep Seabed (GOODS) biogeographic classification [6] (Table 3, Fig. 2B). All records from the intertidal down to $800 \mathrm{~m}$ depth have been allocated to the MEOW scheme as this probably better reflects their patterns than the lower bathyal provinces of the GOODS scheme; the few records from depths $>3000 \mathrm{~m}$ use the GOODS categories. With very few exceptions known distributions fall within only one realm or province. The names of the 12 MEOW realms and 14 GOODS provinces can be found in the tables. Analysis of the differences in numbers of species between regions (MEOW realms or GOODS provinces) must be tempered with an appreciation of historical differences in sampling effort (see next section). Only gross generalisations can be made on the basis of these data.

\section{Results and Discussion}

\section{History of discovery}

While the first isopods were named by Linnaeus, the starting point for the history of discovery for marine Isopoda can be thought of as 1840, the date of publication of Milne Edwards' treatise on Crustacea [7]. In the period 1840-1900 progress was erratic, largely reliant on European or North American expertise and the material basis for isopod taxonomy at that time was limited by available collecting methods and also the technical limitations of the equipment used. Outstanding contributions from this era include the global monographs produced by Danish authors J.C. Schioedte and F. Meinert (1879-1884: Cymothoidae, Aegidae and Corallanidae) [8] and the equally outstanding contribution of Hans Jacob Hansen, also Danish, that included his revisions of the Cirolanidae and Sphaeromatidae [9,10]. British authors, the Reverend T.R.R. Stebbing [11,12] and E. J. Miers $[13,14]$, towards the end of the 19th century (carrying on into the 1920s), described many species from the Indo-West Pacific. Beddard, publishing result from the HMS Challenger expedition also made a significant contribution [15,16]. Théodore Monod, in $>50$ contributions that spanned the Word War II period, made significant marks, one being his monograph of the Gnathiidae [17] and another his review of Cirolanidae [18]. At a regional level the works of Harriet Richardson at the turn of the century made significant and monographic contribution to the isopod fauna of North America [19], while in the early part of the 20th century Keppel Barnard made a huge contribution in documenting South African isopods of which [20,21] are examples. In Australia the major contributors from this era were T. Whitelegge, W. H. Baker and H.M. Hale [22]. H. F. Nierstrasz, in his contributions to the Siboga Expedition, 1923-1941, provided a summary of knowledge to date for the Isopoda [23]. R. J. Menzies (and his collaborators) made a substantial contribution to the isopod fauna of the Americas, principally in the period 1950-1970s; Menzies is perhaps best known for his monograph on the Isopoda of Chile and the Caribbean abyss [24,25] and his revisions of the Limnoriidae [26] and some valviferan genera [27]. In the modern era, the use of SCUBA and fine-mesh epibenthic sleds (first developed by Theodore Mortensen but later successfully developed for ship use by R.J. Menzies) effectively revolutionised the ability to collect small (1-5 mm long) isopods, particularly from shallow subtidal habitats and the continental shelf and slope respectively. From about the mid-1970s the major contributors (and their students) worked on large collections of this new and rich source of specimens, including (within the taxa under consideration) Angelika Brandt, Niel Bruce, Brian Kensley, Oleg Kussakin, Hans-Georg Müller, Gary Poore and Wolfgang Wägele. Figure 3 shows the clear biphasic discovery of new species, the first strong phase during 1880s-1930s and the second during 1980s2000, a pattern common for many taxa. The rate of species discovery has slowed since the 1990s. Almost 20\% of all known species and almost $10 \%$ of genera were described during the 1990s. The rate of description would appear to have slowed but this does not indicate completion of the task (see below).

\section{Morphology}

The isopod body is divided into three regions: a head of fused segments including the first thoracomere; a pereon of 7 segments, usually free; and an abdomen of 5 segments, sometimes fused, plus pleotelson (fused last pleonal segment and telson). The head carries 2 pairs of antennae (antennules and antennae), mandibles, maxillules, maxillae and maxillipeds. The pereon has 7 pairs of pereopods (often but not always similar walking legs; sometimes some are lacking), each of only one branch. The abdomen has 5 pairs of lamellar biramous pleopods sometimes modified, plus a pair of biramous uropods attached to the pleotelson. Females carry eggs, embryos and juveniles in a ventral marsupium derived from the pereopodal coxae (as in all peracarid crustaceans) or in a ventral pouch in some sphaeromatids and cirolanids. Males uniquely bear a pair of stylets on inner edges of the endopods of the second pleopods. Juveniles lack the last pairs of pereopods, hatching as the so-called manca stage, these pereopods appearing and developing in size with successive moults.

Marine isopods range in size from approximately $1 \mathrm{~mm}$ (smallest asellotes and anthuroids, bordering on interstitial or meiofauna size) and $2 \mathrm{~mm}$ (smallest Gnathiidae, Cirolanidae, Sphaeromatidae) to the largest of all isopods, Bathynomus giganteus at over $350 \mathrm{~mm}$ [28]). The overwhelming majority of species are in the size range of 3 to $20 \mathrm{~mm}$. Very few isopods exceed $50 \mathrm{~mm}$. Shallow-water species may be cryptically coloured or patterned [29] though such colours are usually lost on preservation. Pigmented patterns are rare but can be persistent and speciesspecific in genera such as Mesanthura (Anthuridae). Chromatophores often contribute to changing patterns and colours within individuals. Isopods such as sphaeromatids and arcturids living on alga or algal turf may be strongly coloured though such colours are generally cryptic, matching for example the red of coralline algae or blue and green of other algae. Some sand-dwelling species such as serolids and Eurydice (Cirolanidae) are also cryptically coloured. Fish-parasitic and deep-water species are generally without pattern, or weakly coloured, deep-water species generally pale to red pink (Aegidae, some Cirolanidae) or white to pale tan (others). Isopods are exceptionally diverse in body form (Fig. 1) and variously use body shape, ornamentation and setation as apparent camouflage and defensive strategies. The body of basserolids and some serolids and sphaeromatids is flattened to provide the least profile on sediment or a hard substrate. Several arcturoid valviferan families use their elongate cylindrical body to stand erect from their habitat. Antarcturids in particular are covered in strong spination that could be assumed to be defensive.

The transition from free-living predation to parasitism in the Cymothooidea is described under 'Feeding'. Associated with this 

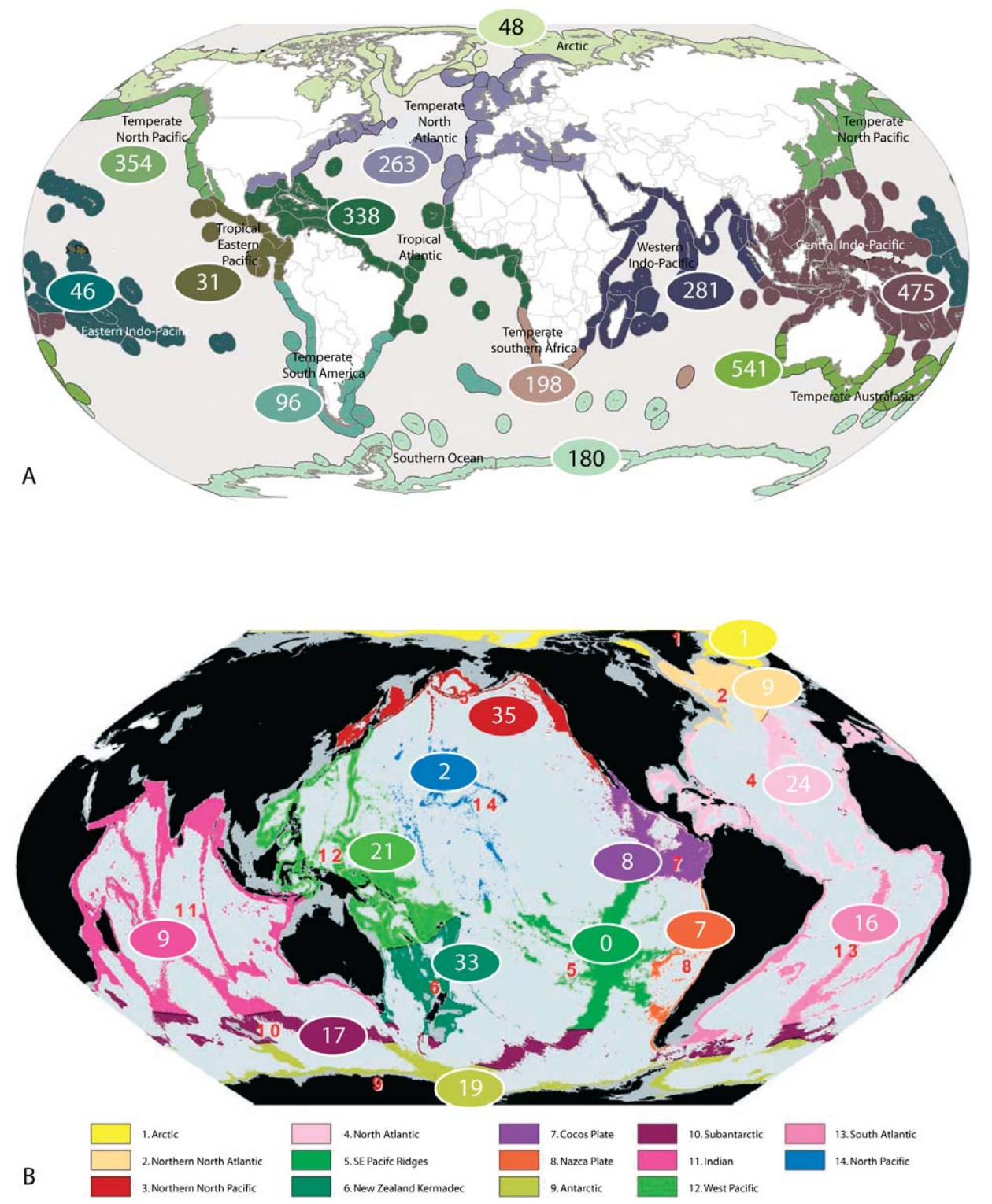

Figure 1. Representative marine isopod forms. Cirolanidae: a, Bathynomus sp. b, Natotolana woodjonesi. c, Cirolana sp. Aegidae: d, Creniola laticauda on sea dragon. Gnathiidae: e, f, Elaphognathia ferox (male and female). Anthuridae: g, Mesanthura astelia. Paranthuridae: $\mathrm{h}$, Paranthura sp. Limnoriiidae: i, Limnoria sp. j, Lynseia himantopoda. Chaetiliidae: k, Austrochaetila capeli. Holognathidae: I, Cleantis phryganaea. Idoteidae: m, Batedotea collingei. Antarcturidae: Antarcturus sp. Arcturidae: o, Neastacilla tharnardi. Serolidae: p, Serolina delaria. Plakarthriidae: q, Plakarthrium australiensis. Sphaeromatidae: $r$, Maricoccus brucei. s, Zuzara venosa. t, Cerceis tridentata.

doi:10.1371/journal.pone.0043529.g001

change in feeding mode is an associated change in morphology. Setae become increasingly fewer as the level of parasitism increases, and the body segments become increasingly smooth. The mouth appendages of worm predators (e.g. Lanocira, Corallanidae) have piercing and suctorial mouthparts, with the maxillule of Lanocira having the form of a large hook, eminently suited to grasping small polychaetes. The feeding habits of some of these carnivorous and scavenging taxa could be seen as a transferable 'pre-adaption' to developing a more parasitic feeding method. In Aegidae, Tridentellidae and Cymothoidae the mouthparts form a distinct 'buccal cone'; typically with the incisory appendages lacking slender setae and the maxilliped, maxilla and maxillule having strongly recurved and hooked robust setae or abrading serrate scales. Pereopod morphology also changes with increasing levels of parasitism - in corallanids the pereopods have relatively few setae but are largely ambulatory. In Aegidae the anterior three pairs of pereopods are prehensile, retain some robust setae, but in some species also display a scraping or 'spoon-like' surface. Finally, the obligate parasitic Cymothoidae have strongly recurved dactyli on all pereopods. Free-living cymothoids have well-developed eyes, as do the commensal families, lack of eyes being associated with extreme turbidity or depth. In Aegidae eyes are absent in the mesopelagic genera but can be large; in many species the eyes occupy the entire dorsal surface of the head. In contrast, the parasitic Cymothoidae have large eyes at the paratenic stage but these become smaller in adults, with the gill and buccal-attaching genera having small eyes or eyes covered by thick cuticle that obscures the ommatidia. As 


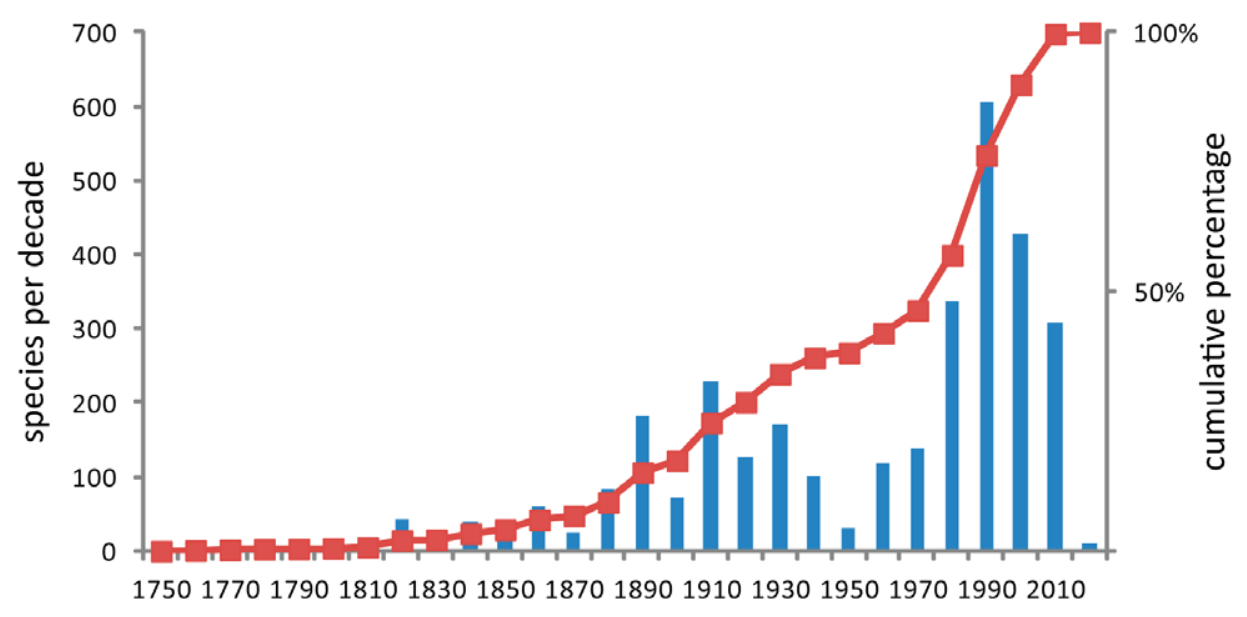

Figure 2. Numbers of marine Isopoda (except Asellota and crustacean symbionts) in biogeographic regions. A. In 12 MEOW biogeographic realms for 2851 species with minimum depths of $<800 \mathrm{~m}$. The few species known to occur in $>1$ realm are assigned only once on the basis of type locality. B. In 14 GOODS lower bathyal provinces for 202 species with minimum depths $>800 \mathrm{~m}$. More detailed data for families are given in Tables 2 and 3 . No species are known to occur in $>1$ province. doi:10.1371/journal.pone.0043529.g002

would be expected, with increasing level of parasitism motility decreases to the state in adult cymothoids that are unable to leave their final host or to swim or crawl. Gnathiid isopods differ from all others in the Cymothooidea in that it is the juvenile or praniza stage that feeds on fish blood; these pranizas are little modified and retain setose, ambulatory pereopods and setae on their pleopods and usually have large eyes; the mouthparts are incisory and suctorial in structure.

\section{Relationships and classification}

The relationship of Isopoda to other Peracarida has not always been well understood. One thing that is almost universally agreed is that Isopoda are monophyletic. Richer \& Scholtz [30] reviewed much of the earliest work in which Isopoda had been various related to Tanaidacea or Amphipoda, or treated as sister taxon to all other peracarid orders. They discussed many morphological traits in detail and concluded on the basis of a cladistic analysis of all malacostracan orders and suborders that Isopoda were more probably sister taxon to Tanaidacea than to any other taxon. Poore [31], also on the basis of a cladistic analysis of morphological characters, concluded that Isopoda were more derived peracaridans than others and sister to Amphipoda, another superabundant group without a carapace or pereopodal exopods. Wilson [32] criticised this result and found some morphological and molecular support for Isopoda and Tanaidacea being similar but not sister-taxa. By his own admission his results were inconclusive but he was supported in part by Tabacaru \& Danielopol [33]. Jenner et al. [34] found conflict between morphological and molecular evidence but found little support for the Isopoda-Amphipoda relationship.

Wägele [35] and later Brandt \& Poore [36] reviewed earlier hypotheses concerning isopod relationships. Wägele's [35,37] 'Hennigian' treatment and Brusca \& Wilson's cladistic analysis [38] both placed Phreatoicidea, Asellota and Oniscidea, all with styliform uropods, at the base of a tree of isopod relationships. They differed in their treatment of these 'short-tailed' taxa, Wägele seeing them as polyphyletic and derived from an ancestral 'flabelliferan' type while Brusca \& Wilson saw this type as derived; they called it the 'long-tailed group' whose members possess expanded pereopodal coxal plates and broad uropods. They also differed in their interpretation of relationships within these long- tailed taxa; Wägele dividing them into separate clades, Cymothoida, Sphaeromatidea and Valvifera, while Brusca \& Wilson found their constituent families only partially resolved. On the basis of molecular studies, Dreyer \& Wägele [39,40] erected a more inclusive taxon that they called Scutocoxifera by adding the Oniscidea to the former flabelliferan families. Relationships within this clade were reappraised using morphology by Brandt \& Poore [36] who largely supported Wägele's classification, if not his evolutionary hypothesis. Wilson's [32] combined morphological and molecular treatment hypothesised several unconventional and conflicting relationships that could not be satisfactorily resolved. Wilson's [32] analysis of the Isopoda using molecular (18S) and morphological data and controversial analytical methods failed to contradict this classification but notably split representatives of the Cymothoida into disparate clades.

Phylogenetic studies at the sub-superfamilial level within the taxa of interest are few. Most examples rely on morphological data and have hypothesised relationships between all isopod taxa [37], between families and genera of Anthuroidea [41,42], between families of Valvifera [43], phylogeny and biogeography of Corallanidae [44] and Gnathiidae [45], or between genera of Idoteidae (now including Holognathidae and Chaetiliidae) [46] and Aegidae [47] and also within genera of Sphaeromatidae [48] and Cirolanidae [49,50].

In the decade since Wetzer [51] lamented the absence of molecular studies of isopod relationships several studies have been published. Held and coworkers compared the phylogeny and biogeography of some genera of Serolidae [52,53] and illuminated cryptic speciation in the Antarctic species Glyptonotus antarcticus and Serolis paradoxa [54,55], Wilson suggested that Gnathiidae are not cymothooids [56], Ketmaier et al. have shown that parasitic feeding strategies in Cymothoidae are independently derived [57], Baratti et al. have resolved relationships between freshwater and anchialine stygiobiont species of American and Mediterranean Cirolanidae [58] and Prevornik et al. [59] elucidated the phylogeny and biogeography of stygial freshwater Monolistra (Sphaeromatidae).

The suborders with marine taxa now recognised are Phoratopodidea, one family and species, Cymothoida (which includes some parasitic families excluded from our review), Limnoriidea, Valvifera and Sphaeromatidea. Table 1 summarizes the current 
Table 1. Families of Isopoda with marine representatives: numbers of marine families, genera and species.

\begin{tabular}{|c|c|c|c|}
\hline \multirow[t]{2}{*}{$\begin{array}{l}\text { Suborder } \\
\text { Superfamily } \\
\text { Family }\end{array}$} & \multicolumn{3}{|c|}{ Numbers of taxa } \\
\hline & families & genera & Species \\
\hline Phoratopodidea & 1 & 1 & 1 \\
\hline Phoratopodidae & 1 & 1 & 1 \\
\hline Cymothoida & 15 & 175 & 1723 \\
\hline Cymothooidea & 9 & 119 & 1152 \\
\hline Aegidae* & & 7 & 147 \\
\hline Anuropidae & & 1 & 10 \\
\hline Barybrotidae & & 1 & 1 \\
\hline Cirolanidae* & & 44 & 412 \\
\hline Corallanidae & & 7 & 74 \\
\hline Cymothoidae* & & 34 & 280 \\
\hline Gnathiidae & & 12 & 205 \\
\hline Protognathiidae & & 1 & 2 \\
\hline Tridentellidae & & 1 & 21 \\
\hline Anthuroidea & 6 & 56 & 571 \\
\hline Antheluridae & & 3 & 18 \\
\hline Anthuridae* & & 24 & 267 \\
\hline Expanathuridae & & 7 & 58 \\
\hline Hyssuridae & & 6 & 39 \\
\hline Leptanthuridae* & & 10 & 96 \\
\hline Paranthuridae & & 6 & 93 \\
\hline Limnoriidea & 3 & 5 & 62 \\
\hline Hadromastacidae & & 1 & 3 \\
\hline Keuphyliidae & & 1 & 1 \\
\hline Limnoriidae & & 3 & 58 \\
\hline Valvifera & 11 & 85 & 603 \\
\hline Antarcturidae & & 17 & 116 \\
\hline Arcturidae & & 15 & 158 \\
\hline Arcturididae & & 1 & 2 \\
\hline Austrarcturellidae & & 5 & 45 \\
\hline Chaetiliidae* & & 12 & 44 \\
\hline Holidoteidae & & 3 & 20 \\
\hline Holognathidae & & 5 & 25 \\
\hline Idoteidae* & & 24 & 185 \\
\hline Pseudidotheidae & & 1 & 4 \\
\hline Rectarcturidae & & 1 & 3 \\
\hline Xenarcturidae & & 1 & 1 \\
\hline Sphaeromatidea & 7 & 124 & 765 \\
\hline Ancinidae & & 2 & 14 \\
\hline Bathynataliidae & & 3 & 4 \\
\hline Basserolidae & & 1 & 2 \\
\hline Plakarthriidae & & 1 & 3 \\
\hline Serolidae & & 22 & 109 \\
\hline Sphaeromatidae* & & 94 & 619 \\
\hline Incertae sedis & & & 2 \\
\hline Tecticipitidae & & 1 & 12 \\
\hline Totals & 37 & 379 & 3154 \\
\hline
\end{tabular}

Families marked * have non-marine/freshwater genera and species not counted in this analysis.

doi:10.1371/journal.pone.0043529.t001 classification that is a widely agreed compromise derived from recent phylogenetic and taxonomic research.

\section{Taxonomic diversity}

Thirty-seven families are discussed here, ranging in diversity from one to hundreds of genera and species (Table 1). Some have freshwater representatives discussed in a similar context by Wilson [60] and not included here.

The groups considered here contribute around 60\% (3154 accepted species in 379 genera in 37 families; Table 1) of all described marine isopods. The suborder Asellota that dominates in the deep sea comprises around 1600 known species, parasitic bopyroids 605 and cryptoniscoids 99 species [1]. Of the five suborders considered here, the Cymothooidea contribute $54 \%$ of all species. This suggests the success of the scavenging, parasitic and predatory life-styles [40] but is also partly attributable to the relatively large size of these species (mostly 3-20 mm) as well as their ease of collecting. Some families are monotypic or have few species while others are exceptionally rich in species. The high numbers of species in some families correlates with high morphological diversity and reflects on underdeveloped taxonomies. This has been counteracted recently with the creation of several families where previously there was one or few, notably in Valvifera [43] and Anthuroidea [41]. The Sphaeromatidae with almost 100 genera and 619 known marine species (and $\sim 65$ in fresh water) can be thought of in terms of several genus-groups with distinctive morphologies that could be considered families in future.

Despite more than 160 years of isopod taxonomy and the large number of described species, many more remain to be described. Species yet to be discovered will come from several sources: study of families that have so far failed to attract taxonomic attention; exploration of new regions such as rocky continental slopes; sampling of difficult habitats; and revelations of cryptic species using new (especially molecular) methods.

High species diversity in some families can be attributed to the recent attention of few taxonomists who dedicated time to describing numerous species and systematic studies: Aegidae, Cymothoidae, Girolanidae (J.G. Schioedte \& F. Meinert, H. -J. Hansen, N.L. Bruce), Anthuroidea (J.-W. Wägele, G.C.B. Poore), Sphaeromatidae (D.M Holdich \& K. Harrison, N.L. Bruce), and Valvifera (G.C.B. Poore, A. Brandt) while others (H. Richardson, K.H. Barnard, B. Kensley, N. Nunomura, R.J. Menzies) each described 250 or more species without specialising. These families still deserve attention but some others remain poorly understood, e.g., Serolidae, Antarcturidae, Arcturidae. The rate of species discovery in the smallest families and in others appears to have plateaued, e.g., Idoteidae, Holidoteidae, Holognathidae, Chaetiliidae. These families are from shallow easily accessible habitats.

\section{Fossils}

The fossil record is moderately strong for certain suborders of Isopoda such a the Cymothoida (Cirolanidae) and Sphaeromatidea, Feldmann and Rust [61] listing 26 species of Palaega, many of which those authors regarded as not belonging to the genus sensu stricto. Unfortunately this uncertainty applies to most fossil isopods [62], which cannot be assigned to a extant families or genera (see several papers by Feldmann), and so do not fit into modern classification. Exceptions are some fine recognizable fossils of Bathynomus, and also of unambiguous Sphaeromatidae [63,64]. Bowman [65] showed that Palaega lamnae could be classified equally as a cirolanid or cymothoid, and most fossils are placed to a 'best fit' rather than from diagnostic morphological characters. Given these limitations the fossil record at contributes minimally to 


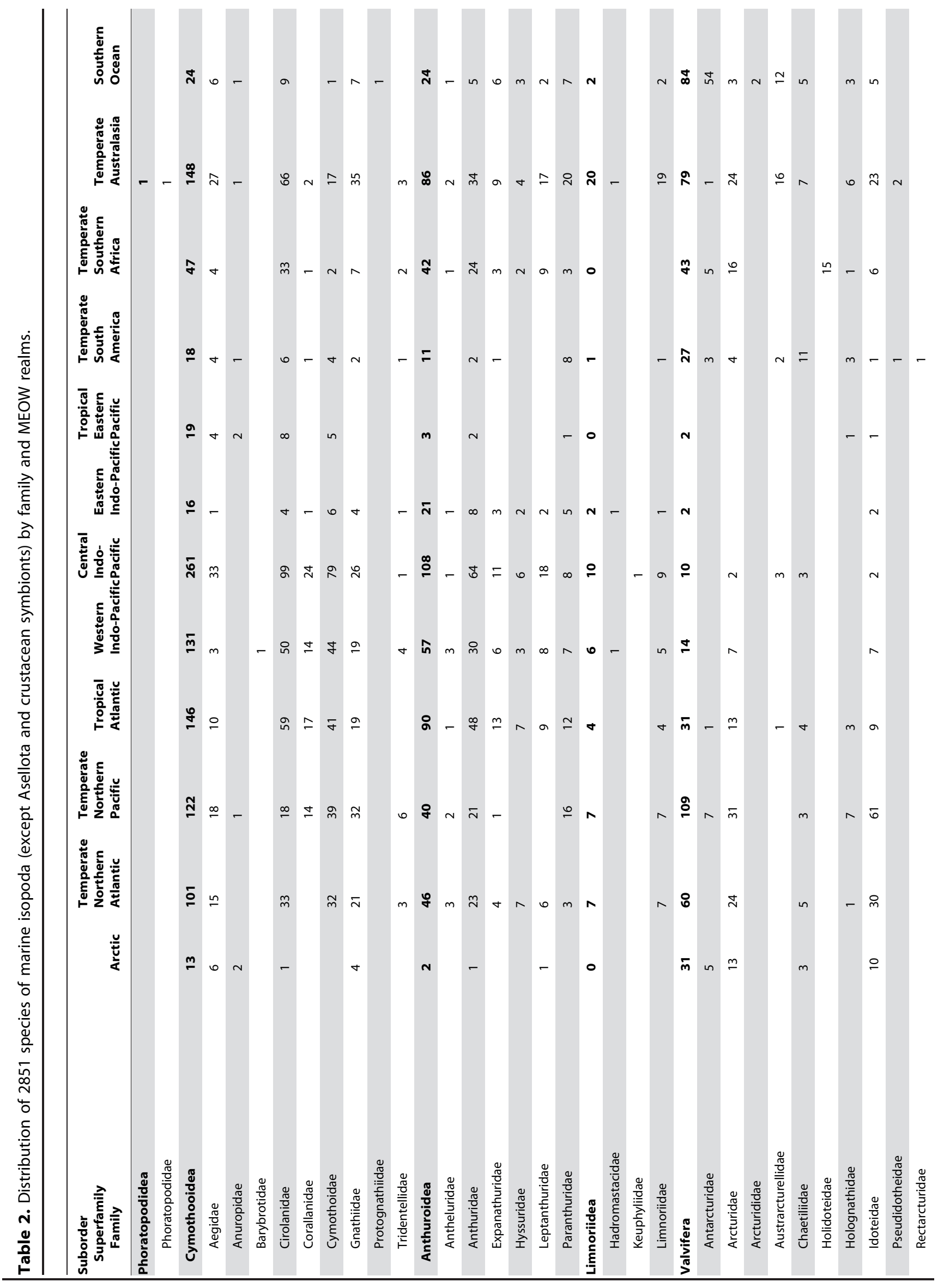




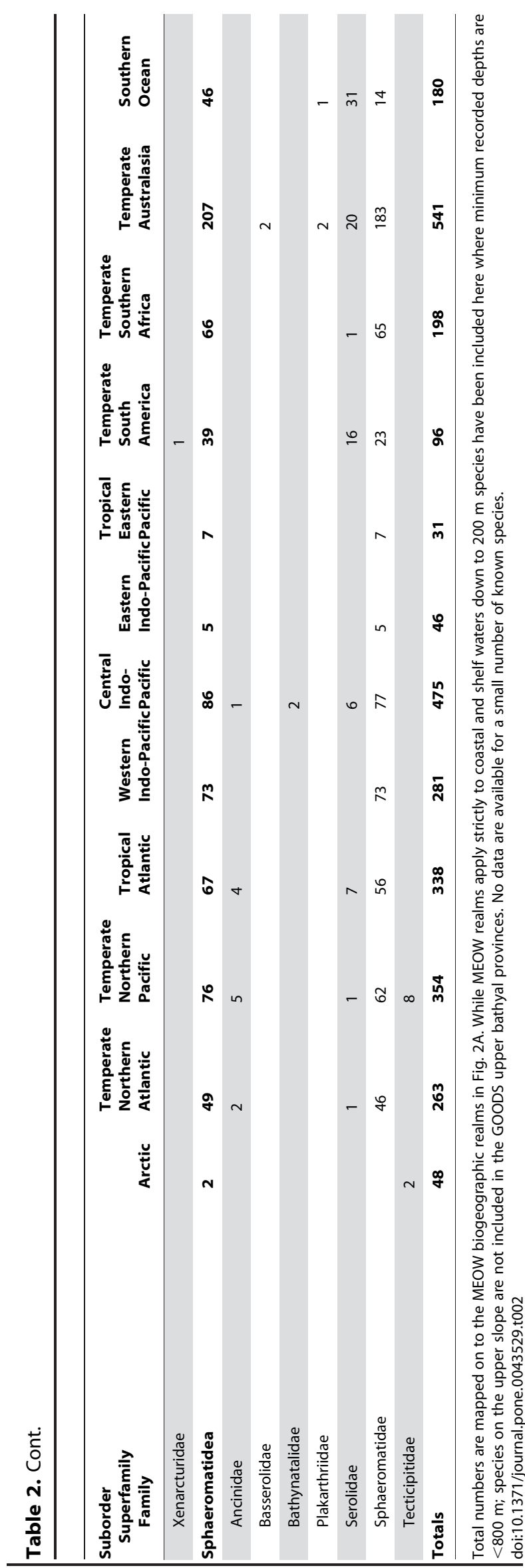

our understanding of isopod diversity, biogeography and evolution. Feldmann \& Charbonnier [66] demonstrated the difficulty of assigning fossils to taxon with the case of a fossil described in a genus of slipper lobster being in fact a species of Cirolana.

\section{Ecology - bathymetry and environments}

Isopods range from the intertidal to the depths of the oceans (Fig. 4). The maritime genera such as Ligia and Tylos belonging to Oniscidea, a generally terrestrial taxon not considered here, live above the high tide. Most species are limited to shallow-water habitats on rocky shores, muddy environments and sandy beaches. The supralittoral Paravireia holdichi Brökeland Wägele \& Bruce, 2001 (Sphaeromatoidea) [67], Campecopea hirsuta (Montagu, 1804) [68] and some species Eurydice [69] are among the few exclusively intertidal representatives, with most intertidal species also extending to at least the shallow subtidal. The deepest recorded species is the antarcturid, Chaetarcturus ultraabyssalis Birstein, 1963 recorded from a trench in the NW Pacific at 6435-7280 metres but none of the families considered are as diverse or rich in species at bathyal and abyssal depths as the Asellota. Most species would appear to have a limited depth range but so few described species have been recorded more than once that this could well be questioned except on theoretical grounds or empirical evidence from other taxa [70]. Some species would appear to show considerable depth ranges (see outliers in Fig. 4) raising suspicions about the accuracy of identifications, especially for those occurring at subtidal and shelf depths as well as beyond a few hundred metres. One striking example is Caecognathia elongata Krøyer, 1849 from the littoral of Greenland down to $3000 \mathrm{~m}$. Of the Cymothoida, more than half the known species of Cirolanidae and Gnathiidae, and threequarters of Corallanidae and Anthuroidea have been recorded from subtidal habitats (Fig. 4). Another cymothoidan family, Aegidae, is distributed differently: many species range widely over shelf and slope depths. More than half of the species of the valviferan families Antarcturidae, Arcturidae and Austrarcturellidae are restricted to shelf depths but a significant fraction either extend to or are confined to slope and abyssal depths. The Idoteidae and Chaetiliidae differ with the vast majority confined to the immediate subtidal or inner shelf and relatively few extending to slope depths. Two-thirds of sphaeromatid species are confined to the shelf, while some extend deeper. Most species of Serolidae are shallow subtidal or shelf species and few can be called deepwater. While the patterns of family depth ranges are similar, differences are more evident at a generic level. For example, while many are strictly intertidal to subtidal (e.g., most Idoteidae) others are strictly abyssal or appearing on the shelf only in Antarctica (e.g., several Antarcturidae, Brucerolis).

Shallow-water isopods inhabit any suitable refugium, including sediments. Crevices, dead barnacle tests, dead mollusc shells (or fragments thereof) worm tubes, under surface of rubble or rocks, algal holdfasts, algal turf, dead wood, sand are suitable habitats. In shallow water isopods generally avoid habitats with high levels of silt, and diversity consequently drops in estuaries, mangroves and coral reef lagoon habitats. In shallow sediments (intertidal to $30 \mathrm{~m}$ ) mobile sands and gravel are strongly preferred; diversity and densities are higher than over stable sand areas with worm tubes or sea grasses.

Sandy beaches with wave action have a characteristic and predictable suite of isopods around the world. Cirolanids are typically present, the dominant intertidal genera being Eurydice and Excirolana, Australia and New Zealand being the only exception with the representative cirolanids being species of Pseudolana, Eurylana and Pseudaega. In the tropics the sphaeromatid genus Sphaeromopsis is widespread, and species of Exosphaeroma occur on 


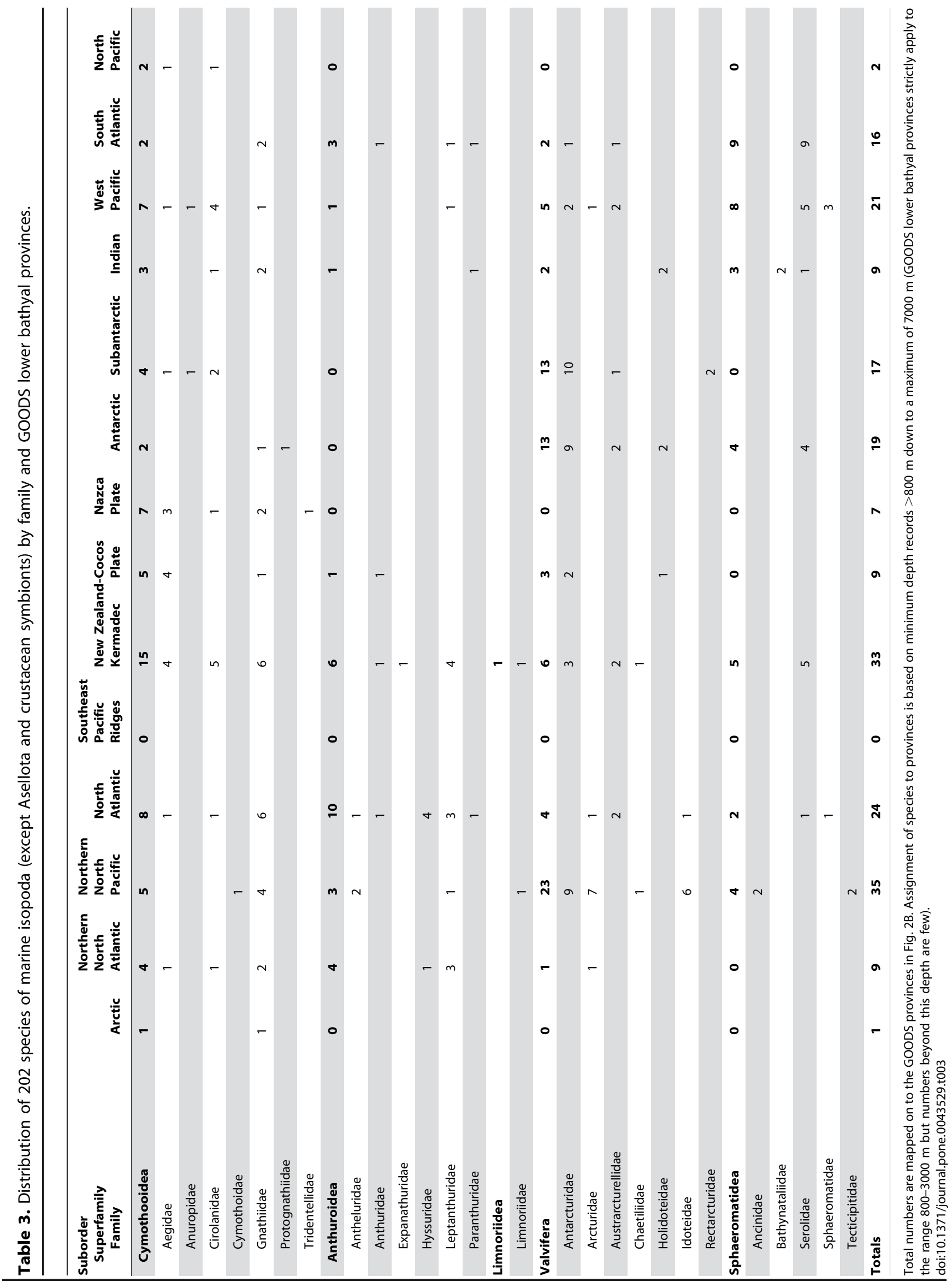




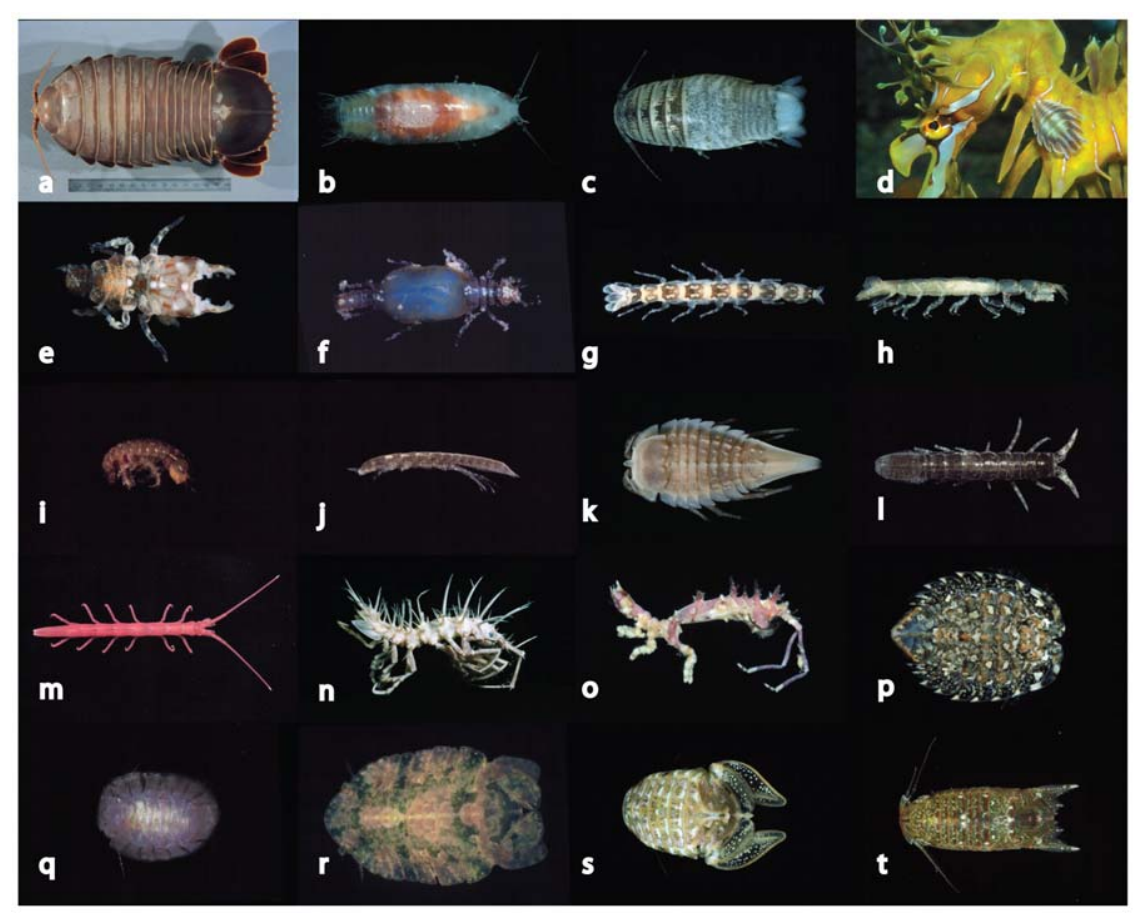

Figure 3. Absolute numbers and cumulative percentage of species of marine Isopoda (3154) published per decade since Linnaeus, 1758.

doi:10.1371/journal.pone.0043529.g003

some beaches. Species of the valviferan genera Chiridotea [71], Chaetilia [72] and Macrochiridothea [73] are present on American and New Zealand beaches, and Serolidae are known from southern South American beaches.

Coral reefs, with high spatial complexity, may have the highest marine isopod diversity per unit area of any habitat, and although the reef flat and outer slope (the 'living reef') has a predictable suite of representative families and genera, it is too diverse to discuss in detail [74-77]. One characteristic that is generally true for coral reefs around the world is that Valvifera are generally rare, and when reported have usually been collected from adjacent off-reef habitats. Recent extensive and thorough collections of isopod made during the CoML-CReefs program (2008-2010) indicated that individual shelf reef regions such as Lizard Island, Great Barrier Reef, Australia, and adjacent outer reef and Heron Island, Australia, have approximately 150-200 species of isopods, not including the off-reef sea floor rubble and sediments.

Macroalgae constitute a major habitat for Limnoriidae, Sphaeromatidae, Idoteidae and Holognathidae in temperate and cool waters. In tropical and subtropical regions algal turf usually contains a restricted assemblage of species of Sphaeromatidae, Anthuroidea and some cirolanids. Certain algae such as Sargassum are used by some Idoteidae and certain genera of Sphaeromatidae such as Cerceis and Cymodoce though these species are not restricted to Sargassum. In contrast, sea grasses seem to host few isopods, the notable exception being some species of the limnoriid genus Limnoria particularly all three species of Lynseia that live as leaf miners [78,79]. The hollow stems of seagrasses also provide the specialist caddis-like home of the holognathid genera Cleantis and Cleantioides. Another specialist plant resource is wood, notably for wood-boring 'gribble' of the genus Limnoria and for the deep-sea valviferan genus Holognathus.

Few species of isopod are genuinely planktonic, although rather more are bentho-planktonic, swim in the plankton when breeding or during the paratenic phase. Bentho-planktonic species occur in the cirolanid genera Eurydice, Natatolana and some Sphaeromatidae, while a paratenic phase is characteristic of the Gnathiidae [80] and Cymothoidae [81]. Genuine meso-planktonic species include Metacirolana caeca and Pontogelos (Cirolanidae), Anuropus (Anuropidae) and Syscenus (Aegidae), and typically have extensive multiocean distribution and lack eyes. Barybrotes indus (Barybrotidae) appears to be a nektonic species. Numerous species have be recorded as rafting on algae and other flotsam but the cosmopolitan Idotea metallica would seem to be the only obligate rafter [82].

Subtidal sediments, ranging from pebbles and gravel through to sand and mud, are rich in isopod species. Particularly rich in shallow waters are clean (largely silt free) mobile sand and gravel such as found at the base of large bommies, in the groove of 'spur and groove' on coral reefs, or where wave and current action keeps the sand mobile. As sediments become silt-laden families such as Cirolanidae and Sphaeromatidae decrease in diversity, while in the deep ocean $(>1000 \mathrm{~m})$ Asellota increase in diversity. Many anthuroids are tolerant of high mud content and survive by building tube-shelters.

Symbioses, beyond that of the parasitic Cymothoidae are not common. In the Cirolanidae the tropical monotypic genus Cartetolana inhabits the oral disk of certain crinoids (e.g., Comanthus spp.) and Neocirolana hermitensis inhabits shells occupied by species of the hermit crab Dardanus. Several species and genera of Sphaeromatidae are known to associate with sponges, the large genus Oxinasphaera appearing to be an obligate sponge associate [83]; Xynosphaera colemani burrows into the tissue of alcyonaceans; and some species of Moruloidea and Cassidias have been reported from gorgonians, their body form mimicking the shape of the polyps [84]. Antarcturids in the deep sea and arcturids at shallower depths are frequently associated with erect corals and hydroids that enable them to filter-feed up off soft sediments [85]. 

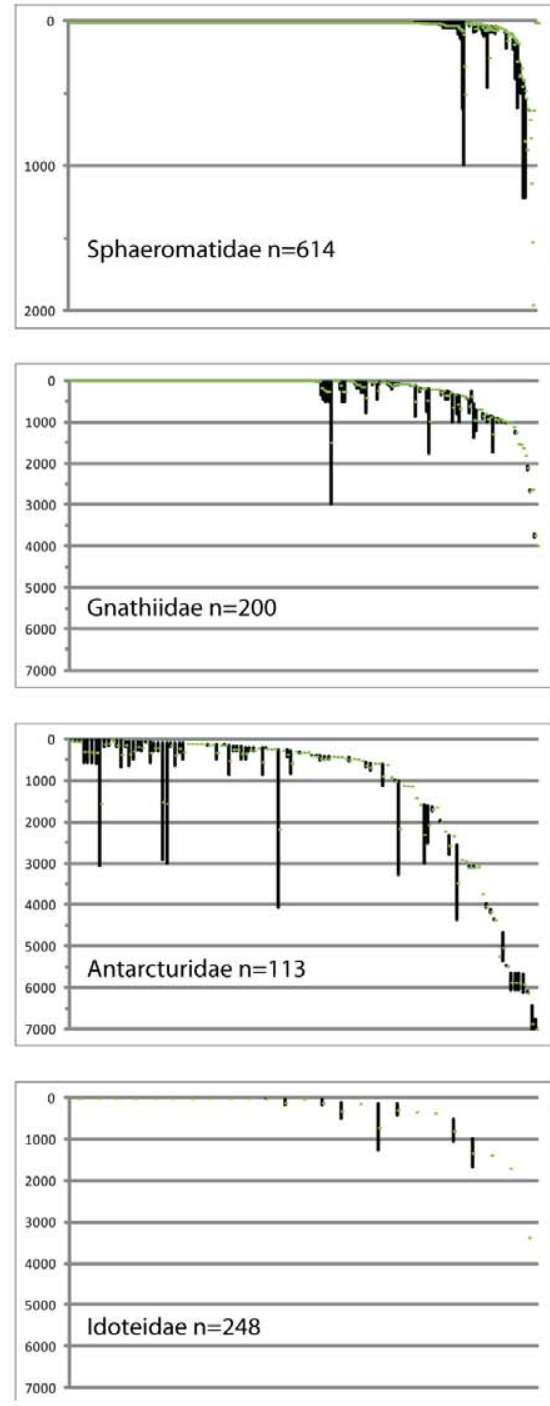
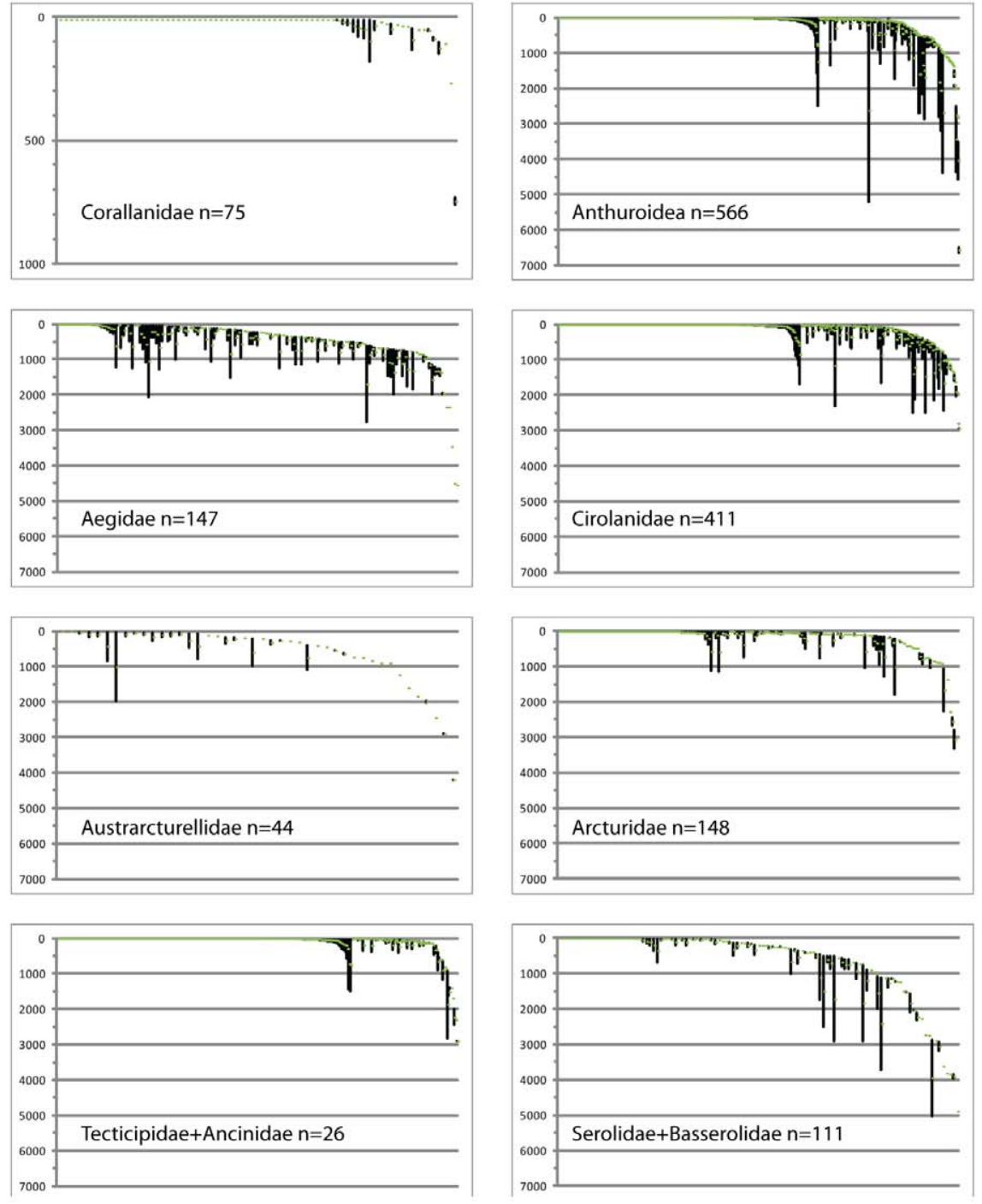

Figure 4. Bathymetric ranges of species of the larger families (and groups of related families) of marine isopod families. Data come from Schotte et al. [2], gaps filled by data from original publications. Species are ranked, left to right, from shallowest minimum depth to deepest, with depth records $<10 \mathrm{~m}$ coalesced as $10 \mathrm{~m}$ for clarity. Numbers of species of each family or family group for which data are readily available are given. Green dots are average depths. Vertical axes are depths in metres, not to the same scale.

doi:10.1371/journal.pone.0043529.g004

Black hydroids may be the obligate substrate of the tropical valviferan Amesopous richardsonae. Other isopods that appear to associate with sponges include some species of Aegidae and Corallanidae and also some Gnathiidae. Some Corallanidae appear to be commensals of tropical fishes, notably Argathona macronema (Corallanidae) and Epulaega lethrina (Aegidae), both species feeding on fish mucus not blood.

\section{Feeding}

Although it is remarkable how few studies have directed research at feeding modes, four broad categories can be recognised as much on the basis of anecdotal evidence as hard data: detritus feeders and browsers, carnivores, parasites, and filter feeders. Detritus feeding is an attributed feeding category, generally applied without direct evidence to groups in which the mandible and molar process are not adapted to parasitic or carnivorous feeding. Typically the Sphaeromatidae are considered to be browsers or detritus feeders, and certainly virtually no species of that family has been shown to be a carnivorous scavenger or predator, although one species has been taken in baited trap and a small number of species appear to have incisory mandibles (e.g., Xynosphaera).

Carnivorous feeders can be further split into three groupsmicropredators, predators and scavengers. The Cirolanidae have species that are active predators such as species of Eurydice and Metacirolana, but the majority are scavengers, including well-known examples such as giant deep-sea isopods of the genus Bathynomus [86]. Cirolanids are voracious scavengers, and can occur in vast numbers, and have been known to reduce a seal carcass to skin and bone overnight [87]. The Cymothooidea include seven families that show a progressive development towards parasitism, culminating in the Cymothoidae that live on the external surfaces and in the buccal and gill cavities of their fish hosts or burrow into the muscle. Carrying cymothoid parasites has been shown to result in parasitic castration [88]. The Corallanidae [89] contain genera that are commensal on fishes, live in sponges and some that are 
micropredators, even known (personal experience) to feed off humans; others feed on worms (e.g. Lanocira), and possess grasping and piercing mouthparts similar to those of the Cymothoidae. The Aegidae [47] are all micropredators of fish, taking a blood meal, and generally not staying on the host. Two aegid genera, Rocinela and Syscenus, are known to stay attached for a period, and Syscenus may attach permanently though this is not known for certain. Cymothoidae are all obligate parasites of fishes, and feed on host tissues and fluids at some stage of their life; they have been shown to possess anticoagulants [90], and it has been convincingly shown that these parasites depress breeding success [91] and have a castration effect on male fish [88].

Data on feeding habits of anthuroids are few but both the leptanthurid genus Accalathura [92] and anthurid genus Cyathura [93] are predators, and this is assumed for other species. Serolidae are predators [94]. Valviferans are variously algal browsers [95] or filter feeders $[85,96]$.

\section{Reproduction}

Isopods retain the ova in a brood pouch, as in other peracarid crustaceans, and release offspring as mancas (juveniles resembling adults except for the absence of the last pair of pereopods), bypassing a larval phase. While gnathiids and cymothoids have a paratenic phase, praniza and aegathoid respectively, these are morphologically mancoid or immature individuals. The brood pouch is composed of oostegites arising usually from the coxae of some or all of pereopods 2-7. There are number of derived conditions including holding the ova and pre-release mancas in invaginations of the ventral body wall (e.g., Excirolana, some sphaeromatids) and also oostegites being lost and replaced by anterior and posterior pockets in the Sphaeromatidae [97]; some genera of Cymothoidae have a posterior fold [98].

Ova size and number of ova are directly correlated to isopod size, small species carrying few ova $(<10)$ while large species have more and usually larger ova (the eggs of Bathynomus species are larger than most species of isopod). Fish-parasites have a large brood pouch, which in gill-attaching genera is sufficiently large to be described as an 'egg sac', carrying a very large number of eggs, and then pre-mancoid young. The number of released mancas is directly related to the size of the isopod, and ranges from 10 to 1,600 individuals [91,99-101].

Males have gonopores on the medially-expanded coxal plates of pereopod 7 that cover the sternum. The pores may be separate or close together and may or may not be at the end of penial processes. In some valviverans the penes are fused into a single process. Sperm transfer is assisted by paired stylets on the inner edge of the endopod of pleopod 2. In some arcturoid valviferans the stylets form a complex interaction with highly modified and grooved first pleopods.

For most isopod species the process of sexual determination is not known. Sexes are usually separate but some are hermaphroditic. Anthuroids generally are protogynous, the terminal swimming males stage being relatively rare in a population [102]. Cymothoidae are obligate parasites of fishes. In those genera that attach in the mouth, gills of body cavity, a small 'dwarf' male is usually associated with a large female. In the externally attaching genera such as Anilocra and Nerocila individuals are protandrous and less likely to occur in pairs; Renocila is an exception.

Strong sexual dimorphism is characteristic of several isopod families, evident most simply in differences in body proportions; females are wider than males in idoteids but narrower in serolids. The pereopods of males of these two families may be more setose than females and males of serolids may have pereopods modified for coitus [103]. The most extreme differences are seen in
Gnathiidae, the adult males of which have obvious and often large mandibles projecting anteriorly on a somewhat quadrate and robust head. Females in contrast have a small and anteriorly rounded or narrowed head and inflated pereon [56,104]. Female Cymothoidae are two to three times as large as their accompanying males, and usually have smaller eyes; the males have a simple bilateral body shape, while females may be axially twisted and have mores strongly developed coxal plates, and may show carinae and lobes on the pereopods that are absent in the male. Sphaeromatidae are often strongly dimorphic, with males showing a high degree of cuticular ornamentation, including prominent spines, variously perforate pleotelson shapes and variously reduced or expanded uropods, whereas in contrast the females present what can be called a simple morphology [105]. For most families the difference is in the primary sexual characters and often the antennule and antenna (more heavily setose in males). In a small number of genera such as Metacirolana and Eurydice and all anthuroids, males undergo a change into a 'swimming male' morphology with enlarged eyes, reduced mouthparts, a more elongate pleon, and the antennule more elongate and with numerous aesthetascs.

Neoteny is a feature of some anthuroid genera, notably within Paranthuridae [106], and is seen also in some deep-sea asellotes.

A haremic breeding structure is known in some Sphaeromatidae [107-109] and all Gnathiidae [80,110].

\section{Biogeography}

About half of all coastal, shelf and upper bathyal species have been recorded in temperate realms, $40 \%$ in tropical regions and the remainder in polar seas (Table 2, Fig. 2A). The greatest concentration of temperate species is in Australasia; more have been recorded from temperate North Pacific than the assumedly better studied North Atlantic. Of tropical regions, the Central Indo-Pacific is home to more species any other region. This is consistent with findings for many other taxa where this region is referred to as the Coral Triangle [111], a centre with extreme species richness from whence diversity declines in all directions but especially into the central Pacific. The numbers of species in nontropical regions are decidedly asymmetrical latitudinally with 1.35 times as many species in temperate Southern Hemisphere than the temperate North Atlantic and northern Pacific, and almost four times as many Antarctic as Arctic species, as has been long demonstrated [112,113]. Difference in sampling effort can not be invoked to explain such differences and our experience in Australasia demonstrates that the asymmetry is greater than the data suggest (see next section). Family dominance was not the same from realm to realm. Valviferans dominated in polar regions, Arcturidae and Idoteidae in the Arctic and Antarcturidae in the Antarctic while these taxa were virtually absent from all tropical regions (except the Tropical Atlantic). The families that dominated in tropical regions (relative to other regimes) are Cirolanidae, Cymothoidae, Anthuridae, Expanathuridae and Leptanthuridae, all predatory or associated in some way with fishes. On the other hand, temperate regions are more favourable for Idoteidae and Sphaeromatidae. Only one large family is endemic to a realm, Holidoteidae in Temperate Southern Africa. Three valviferan families Pseudidotheidae, Rectarcturidae and Xenarcturidae with only five species in total, are found only in Gondwanan continents. Austrarcturellidae concentrated in one realm, Temperate Southern Australasia (all exceptions are southern hemisphere). Basserolidae and Serolidae are concentrated in Antarctica, Temperate Southern Australasia and South America, and Central IndoPacific with outliers in deeper water elsewhere. 
Sampling in deeper waters has been more haphazard and data rely on few expeditions (Table 3, Fig. 2B); The taxa under consideration are less abundant and diverse in these provinces than are the Asellota [114-116]. Generalisations are that more species are known from the deep Antarctic than Arctic, and more from the larger Pacific than Atlantic oceans. Two areas with many species known are the New Zealand-Kermadec province, thanks to the work of several Australian workers, and the Northern North Pacific, thanks to the work of Kussakin [117,118]. Antarcturidae and Serolidae are the most species-rich families, especially in the Southern Hemisphere while Gnathiidae are common in all oceans. The absence of species in the southeastern Pacific Region and presence of only two in the North Pacific surely indicates absence of sampling, especially compared to other Pacific regions.

\section{Sampling and taxonomic gaps}

Shallow depths (intertidal to shelf) of some regions have received considerable attention and may be considered well understood with few species remaining to be discovered: Europe [119] and Scandinavia [120], eastern and western North America [19], perhaps also Antarctica [121], Caribbean Sea [122], the Australian Great Barrier Reef (papers by Bruce and Poore), and South Africa [123]. Many areas have received no sustained taxonomic attention and remain very poorly known, including most of the Indian Ocean in spite of the efforts of B. Kensley and coauthors [124-128], the west coast of Africa, South America, the Pacific islands [129-131], and the Indo-Malaysian triangle including Indonesia and the Philippines [132], the latter a region of known high marine diversity.

Others areas have been well sampled by locally based taxonomists but remain only partially described. These have yielded extensive collections now in museums awaiting description. Notable among these is south-eastern Australia where the continental shelf and slope serolid, sphaeromatid and antarcturid fauna is known to contain dozens of undescribed species. Western and northern Australia are generally poorly explored.

While shallow and easily accessed habitats close to civilisation have been the centre of taxonomic study, soft sediments in the deep sea have also received considerable attention, especially recently in the Atlantic Ocean and Weddell Sea [116,133]. The richness of asellotes has been the principal finding. Broad ranging studies on deep-sea non-asellotes are fewer, exceptions being in Antarctica by Brandt on Serolidae, Cirolanidae and Valvifera [134,135] and Schultz on Valvifera [136], in the North Pacific by Kussakin [117] and the Atlantic by Menzies [24]. Other deep-sea habitats are more difficult to sample, notably hard substrates such as found on seamounts and the steep slopes surrounding the Pacific high islands. Such samples from these habitats that do exist suggest an as yet undocumented fauna.

Cryptic species of Crustacea, those that have so-far not been distinguished morphologically, have been revealed in increasing numbers recently following molecular investigation. Few examples exist for Isopoda, Held's [54,137] studies of Glyptonotus and Ceratoserolis being exceptions and where morphological differences can be found post hoc. Even without the assistance of molecular evidence, species swarms are known to us, e.g., in the sphaeromatid Oxinasphaera [48] and cassidiniines [138]. The Cirolana parva-group is known to be similar, currently about 26 or 27 closely similar species, with at least as many species again in collections, and probably double that still to be collected. Several smaller but similar groups exist in all large cirolanid genera, Bathynomus, Eurydice, Metacirolana, Natatolana, and Cirolana. In Sphaeromatidae cryptic species swarms are suspected within most large genera: Cilicaeopsis, Cilicaea, Paracilicaea, Cymodoce, Dynamene,
Dynamenella, Dynoides, Exosphaeroma, Gnorimosphaeroma, Pseudosphaeroma and Paracassidina. The aegid genera Aega and Aegiochus and anthuroid genera Leptanthura and Paranthura are equally diverse.

Confidence in estimates of the numbers of undescribed species is low. We estimate, largely on the basis of fractions of known species in samples from new environments, that around one fifth of all species in intertidal-upper slope habitats are known. Poore et al. [139] reported $78 \%$ of 110 species in the non-asellote taxa sampled on the slope as new, a figure that remains little changed today. Recent sampling in similar environments in Western Australia has found $83 \%$ of 47 non-asellote species as new [Poore, unpublished]. Incidentally, percentages for asellotes are much higher. Applying this figure to the number so far described from these environments a global estimate of $\sim 14300$ species of nonasellotes is reached. This could be perhaps multiplied by $2-5$ to account for cryptic species reaching 28500-71000. Exploration of the deep sea is less advanced and the 200 species so far described could be only a sample of perhaps ten times as many, i.e. another 2000. In total an estimate for these taxa of 30500-73000 species. Using different methods and starting point our estimate for WoRMS (Appeltans et al. submitted) for all marine isopods was 83000, a figure that may have to be revised upwards if the fraction of asellotes remains around half of all marine isopods.

\section{Human issues - economic and environmental impact}

Bird [140] described how the Florida shark fishery collapsed when cirolanids (Natatolana spp.) swarmed over one summer, eating their way into the living sharks and destroying their vital organs so causing death. In New Zealand and Australia [141,142] cirolanids have been identified as attacking fish caught both in fish traps and trawl nets, at times rendering the fish unsaleable. In 'olden days' charts were marked as 'lousy ground' as indication that there was the potential for swarming cirolanids and therefore a place to be avoided by fishers. Cirolanids have been further used by the shark cartilage industry cleaning the shark carcasses of flesh prior to processing.

Isopods have only occasionally featured as a diet item for humans, with anecdotal accounts of Bathynomus being eaten in the Caribbean and Ligia being occasionally eaten by Polynesians. Medicinal properties have occasionally been attributed to isopods, in the marine context the only reference to our knowledge is that of curative properties attributed to 'fiske bjørn' (Aega spp.) by the ancient Nordics, specifically the dried blood-filled gut.

Species of Limnoria, 'gribble' were notorious for boring into and damaging wharf and ship timber along with two or three species of Sphaeroma [143]. Their effect on marine and estuarine timbers became less serious with the advent of treated timbers, although they are still a problem if not monitored (e.g., New Zealand railway bridge collapse [144]. These species too are examples of translocation in the hulls of wooden ships and some species are now widespread [145]. Other isopods have also been transported more recently, e.g., Cirolana harfordi, Paradella dianae and Paracerceis sculpta to Australia [146] and Pseudosphaeroma within Australasia [147]. Another is Synidotea laticauda from San Francisco, USA, to Europe [148] but misidentifications of species of Synidotea have lead to erroneous reports of widespread translocation of the Japanese species S. laevicaudata [149].

The marine isopod Bathynomus giganteus remains one of the largest mobile marine crustaceans, subject of some wonderment in the popular press and on the web. Accounts of individuals 30 inches long may be far fetched but even at $365 \mathrm{~mm}$ in length the species is a voracious and impressive scavenger in the tropical western Atlantic. 


\section{Acknowledgments}

We thank Mark Costello, Auckland, chairman of the WoRMS Steering Committee for stimulating this contribution to the PLoS One collection of review articles. We thank too Ward Appeltans, Flanders Marine Institute (VLIZ), Oostende, for facilitating additions to and edits of the World List of Marine Freshwater and Terrestrial Isopod Crustaceans hosted as part of WoRMS at VLIZ and the Smithsonian Institution. We thank other

\section{References}

1. Williams JD, Boyko CB (2012) The global diversity of parasitic isopods associated with crustacean hosts (Isopoda: Bopyroidea and Cryptoniscoidea). PLoS ONE 7(4): e35350. doi:35310.31371/journal.pone.0035350 Accessed 28 Jul 2012.

2. Schotte M, Kensley B, Shilling S (1995 onwards) World list of marine, freshwater and terrestrial Crustacea Isopoda. National Museum of Natural History Smithsonian Institution: Washington D.C., USA. Available online at http://wwwnmnhsiedu/iz/isopod/.

3. Schotte M, Boyko CB, Bruce NL, Poore GCB, Taiti S, et al. (2008 onwards) World list of marine freshwater and terrestrial isopod crustaceans. Available online at http://wwwmarinespeciesorg/isopoda/.

4. Anonymous [Wetzer R (2003 onwards) Sphaeromatid isopods worldwide "cute as buttons". http://isopods.nhm.org/. Accessed 2012 July 28.

5. Spalding MD, Fox HE, Allen GR, Davidson N, Ferdaña ZA, et al. (2007) Marine Ecoregions of the World: A Bioregionalization of Coastal and Shelf Areas. BioScience 57: 573-583 http://www.vliz.be/vmdcdata/vlimar/files/ spalding_article.pdf Accessed 2012 July 28.

6. UNESCO (2009) Global Open Oceans and Deep Seabed (GOODS) biogeographic classification. UNESCO-IOC IOC Technical Series 84: 1-87 http://unesdoc.unesco.org/images/0018/001824/182451E.pdf Accessed 2012 July 28 .

7. Milne Edwards H (1840) Histoire naturelle des Crustacés, comprenant l'anatomie, la physiologie et la classification de ces animaux. Paris: Librairie Encyclopédique de Roret. 638 p.

8. Schioedte JC, Meinert F (1879) Symbolae ad monographium Cymothoarum Crustaceorum Isopodum familiae. I. Aegidae. Naturhistorisk Tidsskrift 12: $321-414$

9. Hansen $\mathrm{HJ}$ (1905) On the propagation, structure and classification of the family Sphaeromidae. Quarterly Journal of Microscopical Science 49: 69-135.

10. Hansen HJ (1906) Revision of the European forms of the Cirolaninae, a subfamily of Crustacea, Isopoda. Journal of the Linnean Society of London (Zoology) 29: 337-373.

11. Stebbing TRR (1900) On Crustacea brought by Dr Willey from the South Seas. In: Willey A, editor. Zoological results based on material from New Guinea, New Britain, Loyalty Islands and elsewhere 1895, 1896 and 1897. Cambridge. pp. 609-690.

12. Stebbing TRR (1913) On the Crustacea Isopoda of the 'Porcupine' Expedition. Transactions of the Zoological Society of London 20: 231-246.

13. Miers EJ (1877) On a collection of Crustacea, Decapoda and Isopoda, chiefly from South America, with descriptions of new genera and species. Proceedings of the Zoological Society of London 1877: 653-679, pls 666-669.

14. Miers EJ (1881) Revision of the Idoteidae, a family of sessile-eyed Crustacea. Zoological Journal of the Linnean Society 16: 1-88.

15. Beddard FE (1884) Report on the Isopoda collected by H.M.S. Challenger during the years 1873-76. Part I. - The genus Serolis. Report on the Scientific Results of the Voyage of HMS Challenger during the years 1873-76 Zoology 11: $1-85$, pls I-X

16. Beddard FE (1886) Report on the Isopoda collected by H.M.S. Challenger during the years 1873-76. Part II. Report on the Scientific Results of the Voyage of HMS Challenger during the years 1873-76 Zoology 17: 1-178, pls I-XXV, 171 chart

17. Monod T (1926) Les Gnathiidae. Essai monographique (Morphologie Biologie, Systématique). Mémoires de la Société des Sciences Naturelles du Maroc 13: 1668.

18. Monod T (1930) Contribution a l'étude des "Cirolanidae". Annales des Sciences Naturelles 13: 129-183.

19. Richardson H (1905) A monograph on the isopods of North America. Bulletin of the United States National Museum 54: VII-LIII, 1-727.

20. Barnard KH (1940) Contribution to the crustacean fauna of South Africa. XII. Further additions to the Tanaidacea, Isopoda, and Amphipoda, together with keys for the identification of hitherto recorded marine and freshwater species. Annals of the South African Museum 32: 381-543.

21. Barnard KH (1959) New and little known South African marine isopods (Crustacea). Annals and Magazine of Natural History (ser 13) 1: 715-720.

22. Hale HM (1929) The crustaceans of South Australia. Part 2. Adelaide: South Australian Government Printer. 202-380 p.

23. Nierstrasz HF (1941) Die Isopoden der Siboga-Expedition. IV. Isopoda Genuina. III. Gnathiidea, Anthuridea, Valvifera, Asellota, Phreatocoidea. Siboga-Expeditie 19: 235-308.

24. Menzies RJ (1962) The isopods of abyssal depths in the Atlantic Ocean. Vema Research Series 1: 79-206. members of the Editorial Board of the isopod database and in particular Marilyn Schotte, and the late Brian Kensley, who initiated the checklist at the Smithsonian National Museum of Natural History, Washington.

\section{Author Contributions}

Analyzed the data: GCBP. Wrote the paper: GCBP NLB.

25. Menzies RJ (1962) Reports of the Lund University Chile Expedition 1948-49. 42. The zoogeography, ecology, and systematics of the Chilean marine isopods. Lunds Universitets Arsskrift 2: 1-162.

26. Menzies RJ (1957) The marine borer family Limnoriidae (Crustacea, Isopoda). Part I. Northern and Central America: systematics, distribution, and ecology. Part II: Additions to the systematics. Bulletin of Marine Science of the Gulf and Caribbean 7: 101-200.

27. Menzies RJ (1950) The taxonomy, ecology and distribution of northern California isopods of the genus Idothea with the description of a new species. Wasmann Journal of Biology 8: 155-195.

28. Lowry JK, Dempsey K (2006) The giant deep-sea scavenger genus Bathynomus Crustacea, Isopoda, Cirolanidae) in the Indo-West Pacific, in Richer De Forges, B. \& Justine, J.-L. (eds). Tropical Deep-Sea Benthos, vol. 24. Mémoires du Muséum National d'Histoire Naturelle, Paris 193: 163-192.

29. Guarino SM, Gambardella C, Ianniruberto M, Denicola M (1993) Color polymorphism in Idotea baltica from the Bay of Naples and its ecological significance. Journal of the Marine Biological Association of the United Kingdom 73: 785-794.

30. Richter S, Scholtz G (2001) Phylogenetic analysis of the Malacostraca (Crustacea). Journal of Zoological, Systematic and Evolutionary Research 39: 113-136.

31. Poore GCB (2005) Peracarida: monophyly, relationships and evolutionary success. Nauplius 13: 1-27.

32. Wilson GDF (2009) The phylogenetic position of the Isopoda in the Peracarida (Crustacea: Malacostraca). Arthropod Structure \& Development 67: 159-198.

33. Tabacaru I, Danielopol DL (2011) Essai d'analyse critique des principales hypothèses concernant la phylogénie des malacostracés (Crustacea, Malacostraca). Travaux de l'Institut Spéléologique, Émile Racovitza 50: 87-119.

34. Jenner RA, Dhubhghaill CN, Ferla MA, Wills MA (2009) Eumalacostracan phylogeny and total evidence: limitations of the usual suspects. BMC Evolutionary Biology 9: 21 doi:10.1186/1471-2148-1189-1121 Accessed 28 Jul 2012.

35. Wägele JW (1981) Zur phylogenie der Anthuridea (Crustacea, Isopoda) mit Beitragen zur Lebensweise, Morphologie, Anatomie und Taxonomie. Zoologica (Stuttgart) 132: 1-127.

36. Brandt A, Poore GCB (2003) Higher classification of the flabelliferan and related Isopoda based on a reappraisal of relationships. Invertebrate Systematics 17: 893-923.

37. Wägele J-W (1989) Evolution und phylogenetisches System der Isopoda. Stand der Forschung und neue Erkenntnisse. Zoologica (Stuttgart) 140: 1-262.

38. Brusca RC, Wilson GDF (1991) A phylogenetic analysis of the Isopoda with some classificatory recommendations. Memoirs of the Queensland Museum 31: 143-204.

39. Dreyer H, Wägele J-W (2002) The Scutocoxifera tax. nov. and the information content of nuclear ssu rDNA sequences for reconstruction of isopod phylogeny (Crustacea: Peracarida). Journal of Crustacean Biology 22: 217-234.

40. Dreyer H, Wägele J-W (2001) Parasites of crustaceans (Isopoda: Bopyridae) evolved from fish parasites: molecular and morphological evidence. Zoology (Jena) 103: 157-178.

41. Poore GCB (2001) Families and genera of Isopoda Anthuridea. In: Kensley, B. and Brusca, R.C. Isopod systematics and evolution. Balkema: Rotterdam. Crustacean Issues 13: 63-173.

42. Wägele JW (1980) Zur phylogenie der Anthuridea (Crustacea, Isopoda) mit Beitragen zur Lebensweise, Morphologie, Anatomie und Taxonomie [Doctoral]. Kiel: Christian-Albrechts-Universitat zu Kiel. 192 p.

43. Poore GCB (2001) Isopoda Valvifera: diagnoses and relationships of the families. Journal of Crustacean Biology 21: 213-238.

44. Delaney PM (1989) Phylogeny and biogeography of the marine isopod family Corallanidae (Crustacea, Isopoda, Flabellifera). Contributions in Science, Natural History Museum of Los Angeles County 409: 1-75.

45. Cohen BF, Poore GCB (1994) Phylogeny and biogeography of the Gnathiidae (Crustacea: Isopoda) with descriptions of new genera and species, most from south-eastern Australia. Memoirs of the Museum of Victoria 54: 271-397.

46. Brusca RC (1984) Phylogeny, evolution and biogeography of the marine isopod subfamily Idoteinae (Crustacea: Isopoda: Idoteidae). Transactions of the San Diego Society of Natural History 20: 99-134.

47. Bruce NL (2009) The marine fauna of New Zealand: Isopoda, Aegidae (Crustacea). NIWA Biodiversity Memoir 122: 1-252.

48. Bruce NL (1997) A new genus of marine isopod (Crustacea: Flabellifera: Sphaeromatidae) from Australia and the Indo-Pacific region. Memoirs of the Museum of Victoria 56: 145-234. 
49. Moore W, Brusca RC (2003) A monograph on the isopod genus Colopisthus (Crustacea: Isopoda: Cirolanidae) with the description of a new genus. Journal of Natural History 37: 1329-1399.

50. Riseman SF, Brusca RC (2002) Taxonomy, phylogeny and biogeography of Politolana Bruce, 1981 (Crustacea: Isopoda: Cirolanidae). Zoological Journal of the Linnean Society 134: 57-140.

51. Wetzer R (2001) Hierarchical analysis of mtDNA variations and the use of mtDNA for isopod systematics. Contributions to Zoology 70: 23-39.

52. Held C (2000) Phylogeny and biogeography of serolid isopods (Crustacea, Isopoda, Serolidae) and the use of ribosomal expansion segments in molecular systematics. Molecular Phylogenetics and Evolution 15: 165-178.

53. Held C, Wägele J-W (2000) Temperature and extinction: molecular evidence for extinction and radiation events in Antarctic Serolidae (Crustacea, Isopoda). Zoology (Jena) 103 Supplement III: 102.

54. Held C, Wägele J-W (2005) Cryptic speciation in the giant Antarctic isopod Glyptonotus antarcticus (Isopoda: Valvifera: Chaetiliidae). Scientia Marina 69 (Suppl. 2): 175-181.

55. Leese F, Kop A, Wägele JW, Held C (2008) Cryptic speciation in a benthic isopod from Patagonian and Falkland Island waters and the impact of glaciations on its population structure. Frontiers in Zoology 5: 19.

56. Wilson GDF, Sims CA, Grutter AS (2011) Toward a taxonomy of the Gnathiidae (Isopoda) using juveniles: the external anatomy of Gnathia aureamaculosa zuphea stages using scanning electron microscopy. Journal of Crustacean Biology 31: 509-522.

57. Ketmaier V, Joyce DA, Horton T, Mariani S (2008) A molecular phylogenetic framework for the evolution of parasitic strategies in cymothoid isopods (Crustacea). Journal of Zoological Systematics and Evolutionary Research 46: 19-23.

58. Baratti M, Filippelli M, Nardi F, Messana G (2010) Molecular phylogenetic relationships among some stygobitic cirolanid species (Crustacea, Isopoda). Contributions to Zoology 79: http://dpc.uba.uva.nl/ctz/vol79/nr02/art01. Accessed 2012 July 28.

59. Prevorčnik S, Verovnik R, Zagmajster Z, Sket B (2010) Biogeography and phylogenetic relations within the Dinaric subgenus Monolistra (Microlistra) (Crustacea: Isopoda: Sphaeromatidae), with a description of two new species. Zoological Journal of the Linnean Society 159: 1-21.

60. Wilson GDF (2008) Global diversity of isopod crustaceans (Crustacea; Isopoda) in freshwater. Hydrobiologia 595: 231-240.

61. Feldmann RM, Rust S (2006) Palaega kakatahi n. sp., the first record of a marine fossil isopod from the Pliocene of New Zealand. New Zealand Journal of Geology and Geophysics 49: 411-415.

62. Feldmann RM (2009) A new cirolanid isopod (Crustacea) from the Cretaceous of Lebanon: dermoliths document the pre-molt condition. Journal of Crustacean Biology 29: 373-378.

63. Guinot D, Wilson GDF, Schram FR (2005) Jurassic Isopod (Malacostraca: Peracarida) from Ranville, Normandy, France. Journal Of Paleontology 79: 954-960.

64. Polz H (2005) Zwei neue Asselarten (Crustacea: Isopoda: Scutocoxifera) aus den Plattenkalken von Brunn (Oberkimmeridgium, Mittlere Frankenalb). Archaeopteryx 23: 67-81

65. Bowman TE (1971) Palaega lamnae, new species (Crustacea: Isopoda) from the upper Cretaceous of Texas. Journal of Paleontology 45: 540-541.

66. Feldmann RM, Charbonnier S (2011) Ibacus cottreaui Roger, 1946, reassigned to the isopod genus Cirolana (Cymothoida: Cirolanidae). Journal of Crustacean Biology 31: 317-319.

67. Brökeland W, Wägele J-W, Bruce NL (2001) Paravireia holdichi n. sp., an enigmatic isopod crustacean from the Canary Islands with affinities to species from New Zealand. Organisms, Diversity and Evolution 1: 83-98.

68. Bruce NL, Holdich DM (2002) Revision of the isopod crustacean genus Campecopea (Flabellifera: Sphaeromatidae) with discussion of the phylogenetic significance of dorsal processes. Journal of the Marine Biological Association of the United Kingdom 82: 51-68.

69. Jones DA (1971) The systematics and ecology of some sand beach isopods (Crustacea: Eurydicidae) from the coast of Kenya. Journal of Zoology 165: 201-227.

70. McClain CR, Mincks Hardy S (2010) The dynamics of biogeographic ranges in the deep sea. Proceedings of the Royal Society B: Biological Sciences 277: 3533-3546.

71. McDermott JJ (2001) Biology of Chiridotea caeca (Say, 1818) (Isopoda: Idoteidae) in the surf zone of exposed sandy beaches along the coast of southern New Jersey, USA. Ophelia 55: 123-135.

72. Bastida R, Torti MR (1970) Chaetilia argentina sp. nov., un nuevo aporte al conocimiento de la isopodofauna sudamericana. Bulletin du Muséum national d'Histoire naturelle, Paris 42: 392-400.

73. Hurley DE, Murray RH (1968) A new species of Macrochiridothea from New Zealand, with notes on the idotheid subfamily Chaetilinae (Crustacea Isopoda: Valvifera). Transactions of the Royal Society of New Zealand (Zoology) 10: 241-249.

74. Kensley B (1998) Estimates of species diversity of free-living marine isopod crustaceans on coral reefs. Coral Reefs 17: 83-88.

75. Kensley B (1984) The role of isopod crustaceans in the reef crest community at Carrie Bow Cay, Belize. Marine Ecology 5: 29-44.

76. Kensley B (1988) Preliminary observations on the isopod crustacean fauna of Aldabra Atoll. Bulletin of the Biological Society of Washington 8: 40-44.
77. Bruce NL (2011) Isopoda. In: Richmond MD, editor. A field guide to the seashores of eastern Africa and the western Indian Ocean islands. 3rd ed. Stockholm: Sida, SAREC \& University of Dar es Salaam. pp. 208-211.

78. Van Tussenbroek BI, Brearley A (1998) Isopod burrowing in leaves of turtle grass, Thalassia testudinum, in a Mexican Caribbean reef lagoon. Marine and Freshwater Research 49: 525-531.

79. Brearley A, Walker DI (1993) Isopod borers in seagrass species from southwestern Australia. In: Wells FE, Walker DI, Kirkman H, Lethbridge R, editors. The marine flora and fauna of Rottnest Island, Western Australia. Perth: Western Australian Museum. pp. 415-428.

80. Smit NJ, Davies AJ (2004) The curious life-style of the parasitic stages of gnathiid isopods. Advances in Parasitology 58: 290-391.

81. Bunkley-Williams L, Williams EH (1998) Isopods associated with fishes: a synopsis and corrections. Journal of Parasitology 84: 893-896.

82. Thiel M, Gutow L (2005) The ecology of rafting in the marine environment. II. The rafting organisms and community. Oceanography And Marine Biology: An Annual Review 43: 279-418.

83. Bruce NL (1997) Order Isopoda. Sea Lice. In: Richmond MD, editor. A guide to the seashores of eastern Africa and the western Indian Ocean Islands: SIDA/ SAREC. pp. 198-201.

84. Bruce NL (2003) New genera and species of sphaeromatid isopod crustaceans from Australian marine coastal waters. Memoirs of Museum Victoria 60: 309370 .

85. Wägele JW (1987) The feeding mechanism of Antarcturus and a redescription of A. spinacoronatus Schultz, 1978 (Crustacea: Isopoda: Valvifera). Philosophical Transactions of the Royal Society of London B 316: 429-458.

86. Barradas-Ortiz C, Briones-Fourzán P, Lozano-Alvarez E (2003) Seasonal reproduction and feeding ecology of giant isopods Bathynomus giganteus from the continental slope of the Yucatán Peninsula. Deep-Sea Research Part I: Oceanographic Research Papers 50: 495-513.

87. Wong YM, Moore PG (1996) Observations on the activity and life history of the scavenging isopod Natatolana borealis Lilljeborg (Isopoda: Cirolanidae) from Loch Fyne, Scotland. Estuarine, Coastal and Shelf Science 42: 247-262.

88. Fogelman RM, Kuris AM, Grutter AS (2009) Parasitic castration of a vertebrate: Effect of the cymothoid isopod, Anilocra apogonae, on the five-lined cardinalfish, Cheilodipterus quinquelineatus. International Journal for Parasitology 39: 577-583.

89. Semmens BX, Luke KE, Bush PG, McCoy CMR, Johnson BC (2006) Isopod infestation of postspawning Nassau grouper around little Cayman Island. Journal of Fish Biology 69: 933-937.

90. Romestand B, Janicot M, Trilles JP (1977) Modifications tissulaires et réactions de defense chez quelques téleostéens parasités par les Cymothoidae (Crustacés, Isopodes, Hématophages). Annales de Parasitologie Humaine et Comparée: 177-180.

91. Adlard RD, Lester RJG (1995) The life cycle and biology of Anilocra pomacentri (Isopoda: Cymothoidae), an ectoparasitic isopod of the coral reef fish, Chromis nitida (Perciformes: Pomacentridae). Australian Journal of Zoology 43: 271282

92. Wägele JW (1985) Observations on nutrition and ultrastructure of digestive tract and fat body of the giant paranthurid Accalathura gigantissima Kussakin. Polar Biology 4: 33-43.

93. Wägele JW (1979) Die Homologie der Mundwerkzeuge von Cyathura carinate (Krover, 1847) (Crustacea, Isopoda, Anthuridea). Zoologischer Anzeiger 203: 334-341.

94. White MG (1972) Descriptive and biological notes on the rare Antarctic isopod Serolis ovata Sheppard (Crustacea: Flabellifera). British Antarctic Survey Bulletin 27: 139-144.

95. Boström C, Mattila J (2005) Effects of isopod grazing: an experimental comparison in temperate (Idotea balthica, Baltic Sea, Finland) and subtropical (Erichsonella attenuata, Gulf of Mexico, U.S.A.) ecosystems. Crustaceana 78: 185200 .

96. Moreira PS (1973) Food and feeding behavior of Arcturella sawayae Moreira, 1973 (Crustacea, Isopoda, Valvifera). Boletim do Zoologia e Biologia Marina, ns, Sao Paulo 30: 217-232.

97. Harrison K (1984) The morphology of the sphaeromatid brood pouch Crustacea: Isopoda: Sphaeromatidae). Zoological Journal of the Linnean Society $82: 363-407$

98. Bruce NL (1987) Australian species of Nerocila Leach, 1818, and Creniola n. gen. (Isopoda: Cymothoidae), crustacean parasites of marine fishes. Records of the Australian Museum 39: 355-412.

99. Brusca RC (1981) A monograph on the Isopoda Cymothoidae (Crustacea) of the eastern Pacific. Zoological Journal of the Linnean Society 73: 117-199.

100. Maxwell JGH (1982) Infestation of the jack mackerel, Trachurus declivis (Jenyns), with the cymothoid isopod, Ceratothoa imbricatus (Fabricius), in south eastern Australian waters. Journal of Fish Biology 20: 34-39.

101. Bruce NL (1995) Range extension of the mangrove dwelling isopod genus Ceratolana Bowman (Cirolanidae). Crustaceana 68: 123-125.

102. Bamber RN (1985) The autecology of Cyathura carinata (Crustacea: Isopoda) in a cooling water discharge lagoon. Journal of the Marine Biological Association of the United Kingdom 65: 181-194.

103. Poore GCB (1987) Serolina, a new genus for Serolis minuta Beddard (Crustacea: Isopoda: Serolidae) with descriptions of eight new species from Australia. Memoirs of the National Museum of Victoria 48: 141-189. 
104. Tanaka K (2006) Biology of gnathiid isopods (1). External morphology and classification. Aquabiology 28: 82-87.

105. Shuster SM (1991) The ecology of breeding females and the evolution of polygyny in Paracerceis sculpta, a marine isopod crustacean. In: Bauer R, Martin J, editors. Crustacean sexual biology. New York: Columbia University Press. pp. 91-110.

106. Poore GCB (1984) Colanthura, Califanthura, Cruranthura and Cruregens, related genera of the Paranthuridae. Journal of Natural History 18: 697-715.

107. Jormalainen V, Shuster SM, Wildley HC (1999) Reproductive anatomy, precopulatory mate guarding, and paternity in the Socorro isopod in Thermosphaera thermophilum. Marine and Freshwater Behaviour and Physiology 32: $39-56$.

108. Shuster SM (1989) Male alternative reproductive strategies in a marine isopod crustacean (Paracerceis sculpta): the use of genetic markers to measure differences in fertilization success among a-males, B-males, and y-males. Evolution 43: 1683-1698.

109. Shuster SM, Wade MJ (1991) Equal mating success among male reproductive strategies in a marine isopod. Nature 350: 608-609.

110. Tanaka K (2006) Biology of gnathiid isopods (2). Life cycle, parasitism and habitat utilization. Aquabiology 28: 199-204.

111. Barber P (2009) The challenge of understanding the Coral Triangle biodiversity hotspot. Journal of Biogeography 36: 1845-1846.

112. Clarke A (2008) Antarctic marine benthic diversity: patterns and processes Journal of Experimental Marine Biology and Ecology 366: 48-55.

113. Brey T, Klages M, Dahm C, Gorny M, Gutt J, et al. (1994) Antarctic benthic diversity. Nature 368: 297.

114. Wilson GDF (1998) Historical influences on deep-sea isopod diversity in the Atlantic Ocean. Deep-Sea Research 45: 279-301.

115. Ebbe B, Billett DSM, Brandt A, Ellingsen K, Glover AG, et al. (2010) Diversity of abyssal marine life. In: McIntyre AD, editor. Life in the world's oceans: diversity, distribution, and abundance. Oxford: Wiley-Blackwell. pp. 139-160.

116. Brandt A, Gooday A, Brandao SN, Brix S, Brokeland W, et al. (2007) First insights into the biodiversity and biogeography of the Southern Ocean deep sea. Nature 447.

117. Kussakin OG (1982) Marine and brackish-water Crustacea (Isopoda) of cold and temperate waters of the Northern Hemisphere. Suborders Anthuridea, Microcereberidea, Valvifera, Tyloidea. Opredeliteli po Faune SSR, Akademiya Nauk, SSSR 131: 1-461.

118. Kussakin OG (1979) Marine and brackish-water Crustacea (Isopoda) of cold and temperate waters of the Northern Hemisphere. Suborder Flabellifera. Opredeliteli po Faune SSR, Akademiya Nauk, SSSR 122: 1-472.

119. Naylor E (1972) Synopses of the British Fauna (New Series) No. 3, British marine isopods. London and New York: Academic Press. 86 p.

120. Sars GO (1896-1899) An account of the Crustacea of Norway with short descriptions and figures of all the species. Vol. 2. Isopoda. Bergen: Bergen Museum. 270 p.

121. Wägele J-W (1991) Synopses of the Antarctic Benthos. (eds), Wägele, J.-W. \& Sieg, J. Vol. 2. Antarctic Isopoda Valvifera. Königstein: Koeltz Scientific Books. 213 p.

122. Kensley B, Schotte M (1989) Guide to the marine isopod crustaceans of the Caribbean. Washington, D.C., and London: Smithsonian Institution Press. $308 \mathrm{p}$.

123. Kensley B (1978) Guide to the marine isopods of southern Africa. Cape Town.: Trustees of the South African Museum. 173 p.

124. Kensley B (2001) Biogeography of the marine Isopoda of the Indian Ocean, with a check-list of species and records. In: Kensley, B. and Brusca, R.C. Isopod systematics and evolution. Balkema: Rotterdam. Crustacean Issues 13: 205-264.

125. Kensley B, Schotte M (2002) New species and records of Asellota from the Indian Ocean (Crustacea: Peracarida: Isopoda). Journal of Natural History 36: 1421-1461.

126. Schotte M, Kensley B (2005) New species and records of Flabellifera from the Indian Ocean (Crustacea: Peracarida: Isopoda). Journal of Natural History 39: $1211-1282$
127. Kensley B, Schotte M, Poore GCB (2007) New species and records of valviferan isopods (Crustacea: Isopoda: Valvifera) from the Indian Ocean. Proceedings of the Biological Society of Washington 120: 429-445.

128. Kensley B, Schotte M, Poore GCB (2009) Gnathiid isopods (Crustacea: Isopoda: Gnathiidae), mostly new, from the Indian Ocean. Proceedings of the Biological Society of Washington 122: 32-51.

129. Müller HG (1993) Paranthurid isopods from French Polynesian coral reefs, including descriptions of six new species (Crustacea: Peracarida). Cahiers de Biologie Marine 24: 289-341.

130. Müller H-G (1991) Sphaeromatidae fom coral reefs of the Society Islands, French Polynesia (Crustacea: Isopoda). Cahiers de Biologie Marine 32: 83-104.

131. Müller H-G (1991) Corallanidae from Bora Bora and Moorea, Society Islands, with description of a new species of Corallana (Crustacea: Isopoda: Cymothoidae). Cahiers de Biologie Marine 32: 451-468.

132. Müller H-G (1993) Gnathiidae from Coral Reefs in the Tioman Archipelago, Malaysia, with description of two new species (Crustacea: Isopoda: Cymothoidea). Mitteilungen aus dem Zoologischen Museum in Berlin 69: 3-17.

133. Brandt A, Brix S, Brökeland W, Choudhury M, Kaiser S, et al. (2007) Deep-sea isopod biodiversity, abundance, and endemism in the Atlantic sector of the Southern Ocean-Results from the ANDEEP I-III expeditions. Deep Sea Research Part II: Topical Studies in Oceanography 54: 1760-1775.

134. Brandt A (1988) Antarctic Serolidae and Cirolanidae (Crustacea: Isopoda): new genera, new species, and redescription. Königstein: Koeltz Scientific Books. $143 \mathrm{p}$.

135. Brandt A (1990) Antarctic valviferans (Crustacea, Isopoda, Valvifera) new genera, new species and redescriptions. Leiden: E.J. Brill. 176 p.

136. Schultz GA (1981) Arcturidae from the Antarctic and Southern Seas (Isopoda, Valvifera) Part I. In: Kornicker, L. S. (ed.), Biology of the Antarctic Seas 10. Antarctic Research Series 32: 63-94.

137. Held C (2003) Molecular evidence for cryptic speciation within the widespread Antarctic crustacean Ceratoserolis trilobitoides (Crustacea, Isopoda). In: Huiskes AHL, Gieskes WWC, Rozema J, Schorno RML, van der Vies SM et al, editors. Antarctic biology in a global context. Leiden: Backhuys. pp. 135-139.

138. Bruce NL (1994) The Cassidininae Hansen, 1905 (Crustacea: Isopoda: Sphaeromatidae) of Australia. Journal of Natural History 28: 1077-1173.

139. Poore GCB, Just J, Cohen BF (1994) Composition and diversity of Crustacea Isopoda of the southeastern Australian continental slope. Deep-Sea Research 41: 677-693.

140. Anonymous (1978) Pat Bird receives pilot funds for isopod study from Sea Grant. Mote Marine Laboratory News Dec 1978.

141. Hale HM (1925) Review of Australian isopods of the cymothoid group. Part I. Transactions of the Royal Society of South Australia 49: 128-185.

142. Bruce NL (1986) Cirolanidae (Crustacea: Isopoda) of Australia. Records of the Australian Museum, Supplement 6: 1-239.

143. Ray DL (1959) Nutritional physiology of Limnoria. In: Ray DL, editor. Marine boring and fouling organisms. Washington: University of Washington Press. pp. $46-61$.

144. Bruce NL, Gordon D (2005, unpublished) Interim report on degradation of marine timber by invertebrates at Nuhaka rail bridge. NIWA Client Report: 14.

145. Cookson LJ (1991) Australasian species of Limnoriidae (Crustacea: Isopoda). Memoirs of the Museum of Victoria 52: 137-262.

146. Poore GCB, Storey M (1999) Soft sediment Crustacea of Port Phillip Bay. Centre for Research on Introduced Marine Pests, CSIRO Marine Research, Technical Report 20: 150-170.

147. Bruce NL, Wetzer R (2008) New Zealand exports: Pseudosphaeroma Chilton, 1909 (Isopoda: Sphaeromatidae), a Southern Hemisphere genus introduced to the Pacific coast of North America. Zootaxa 1908: 51-56.

148. Cuesta JA, Serrano L, Bravo MR, Toja J (1996) Four new crustaceans in the Guadalquiver River estuary (SW Spain), including an introduced species. Limnética 12: 41-45.

149. Poore GCB (1996) Species differentiation in Synidotea (Isopoda: Idoteidae) and recognition of introduced marine species: a reply to Chapman and Carlton. Journal of Crustacean Biology 16: 384-394. 